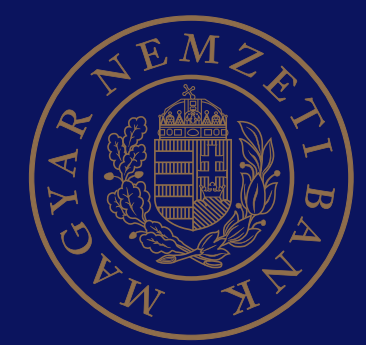

Álmos Telegdy

Public Wage Spillovers:

\title{
The Role of Individual Characteristics and Employer Wage Policies
}

MNB Working Papers 4

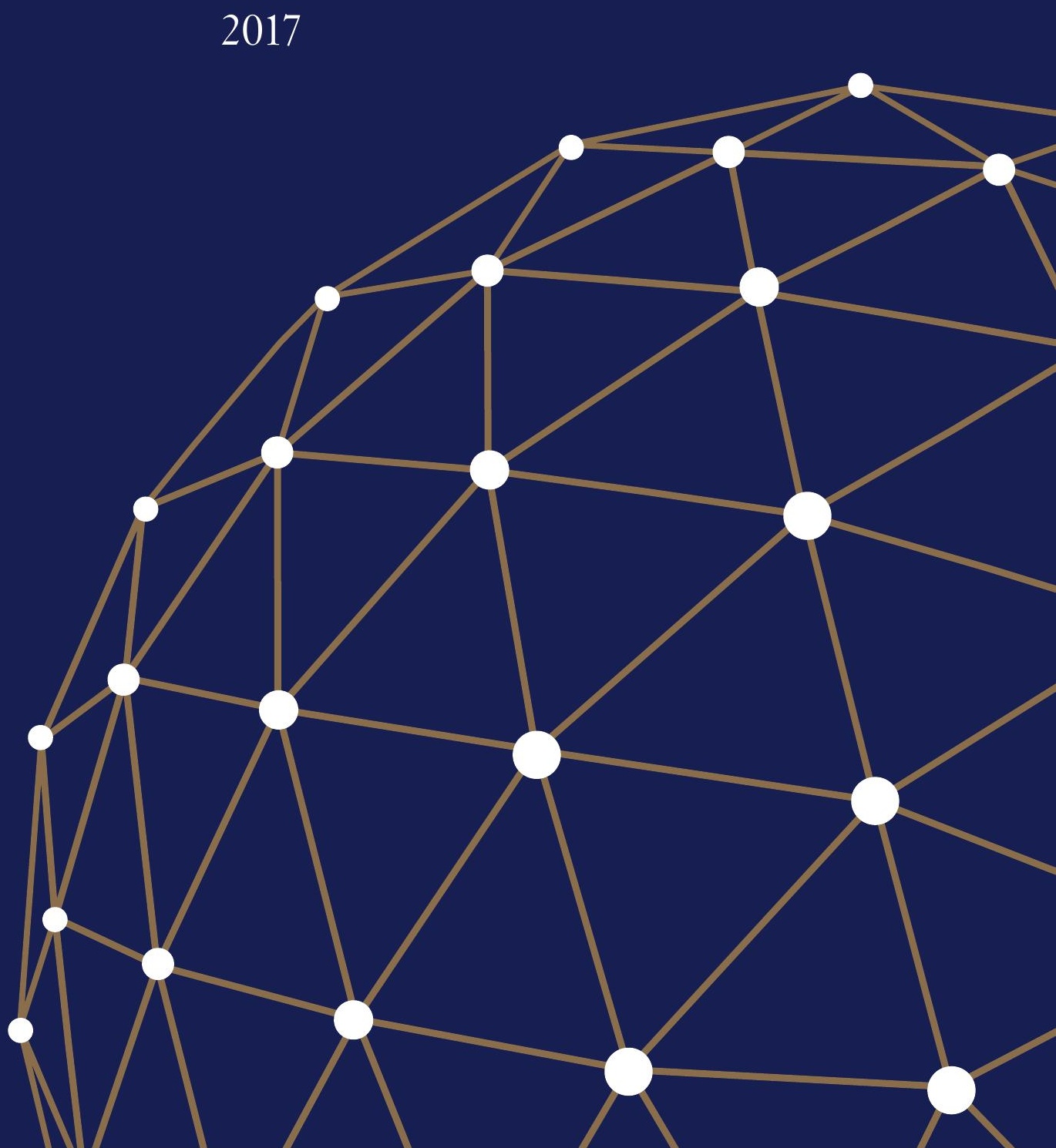





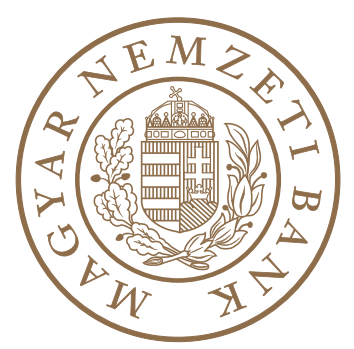

Álmos Telegdy

\section{Public Wage Spillovers: \\ The Role of Individual Characteristics and Employer Wage Policies}

MNB Working Papers 4 2017

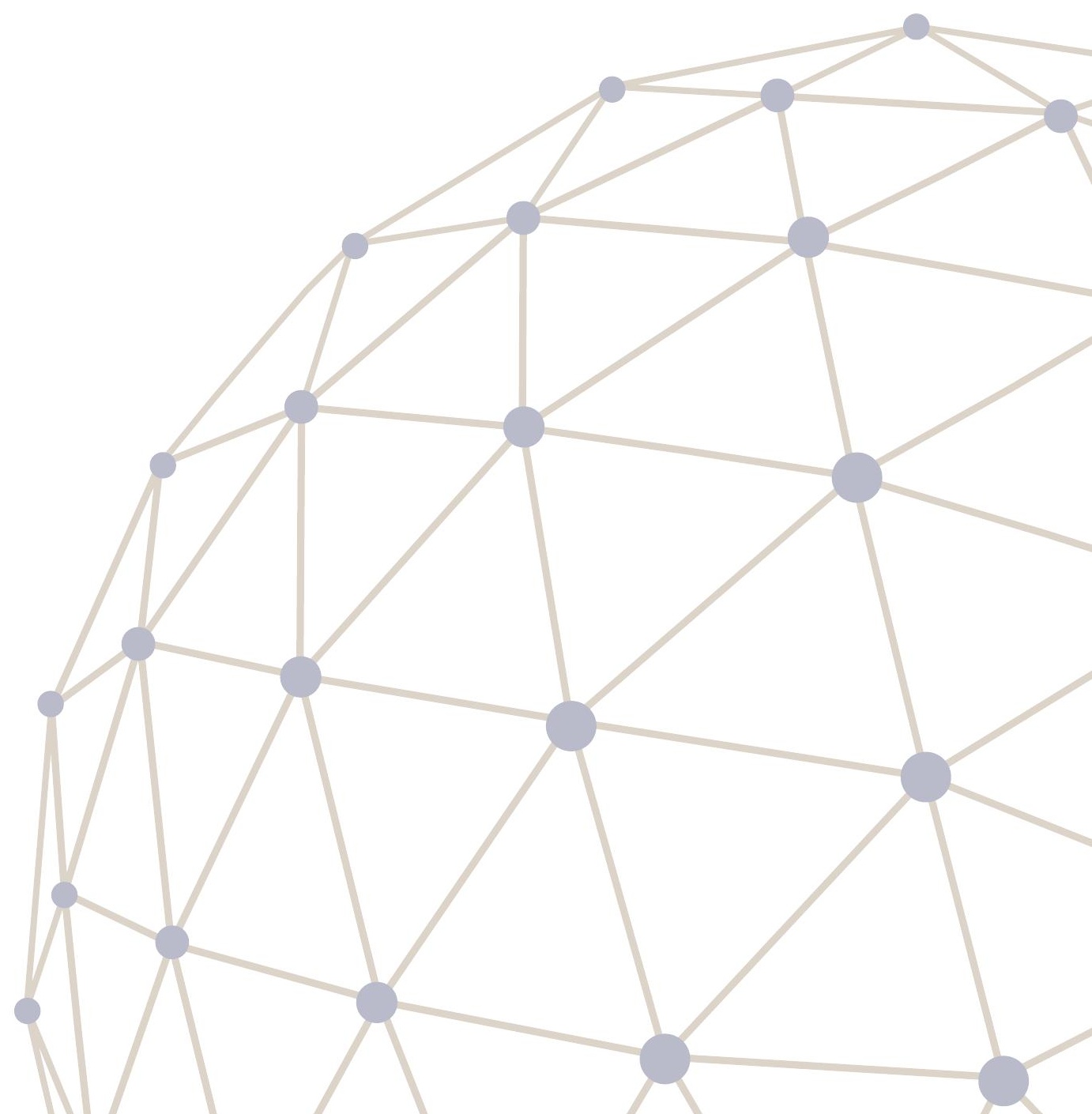


The views expressed are those of the authors' and do not necessarily reflect the official view of the central bank of Hungary (Magyar Nemzeti Bank).

MNB Working Papers 2017/4

\section{Public Wage Spillovers: The Role of Individual Characteristics and Employer Wage Policies}

(Bérátterjedések a köz- és a magánszféra között: az egyéni jellemzők és a vállalati bérpolitikák hatásai)

Written by Álmos Telegdy*

Budapest, March 2017

Published by the Magyar Nemzeti Bank

Publisher in charge: Eszter Hergár

H-1054 Budapest, Szabadság tér 9.

www.mnb.hu

ISSN 1585-5600 (online)

* National Bank of Hungary, Central European University and Institute of Economics, Centre for Economic and Regional Studies - Hungarian Academy of Sciences (CERS-IE). I thank John Sutherland Earle, Péter Elek, Győző Gyöngyösi, Gábor Kézdi, István Kónya, Miklós Koren, János Köllő, Vassilis Monastiriotis, Ágnes Szabó-Morvai and Mirco Tonin for useful advice, John Harbord for editorial assistance and Szilvia Téglás for data cleaning. The data cleaning was executed by Rita Pető, Péter Révész and the Data Sources Department of the CERS-IE. This research was supported by Grant No. 78,255 of the Hungarian Scientific Research Fund. The paper benefited from presentations at the Yearly Conference of the Hungarian Economic Association (2016), the Seminar Series of the CERS-IE Labor Market Group, the Lunch Seminar Series of the CEU Economics Department, the Luis-André Gerard-Varet Conference (2013), the Congress of the European Economic Association (2014), the Conference of the European Association of Labour Economists (2014) and the Conference of Hungarian Labor Economists (Szirák, 2016). The views expressed in this paper are those of the author's and do not necessary reflect the official view of the National Bank of Hungary. All errors are my own. 
Public Wage Spillovers: The Role of Individual Characteristics and Employer Wage Policies

Álmos Telegdy*

January 2017

\begin{abstract}
Using a large and unexpected public wage increase in Hungary which changed the public wage premium in 2002 from -17 to +7.5 percent from one month to the next, I study wage spillovers from the public to the corporate sector. I proxy the exposure of corporate workers to the public sector with the variation of the share of public sector employment within labor market segments defined by gender, experience, occupation and region. Controlling for worker-firm joint fixed effects, the analysis finds that the public wage increase induced a 1.4 percentage points wage differential between two workers situated at the $25^{\text {th }}$ and the $75^{\text {th }}$ percentile of the exposure measure, which corresponds to an elasticity of 0.42 . The firm's exposure to the public sector (measured as the average of individual exposures of the firm's workforce) produces twice as high wage effects and a corresponding elasticity of 0.96 . The spillover affected primarily the wages of males, young workers and the highly educated. The analysis also finds that employers raised the wages of incumbent, rather than, newly hired employees, and that bonuses increased more than regular wages.
\end{abstract}

Keywords: Wage Spillover; Public Sector; Employer Wage Effects; Hungary

JEL codes: J23, J31, J45

\title{
Összefoglaló
}

A tanulmány közszféra bérszínvonalának hatásait vizsgálja a vállalatok bérezésére. Ehhez a 2002-ben történt, nagyarányú és váratlan közbéremelést használja fel, amely a közbérek átlagosan 17 százalékos lemaradását a vállalati bérezéshez képest egy 7.5 százalékos prémiummá változtatta. A vállalati dolgozók kitettségét a közszférának azzal mérem, hogy egyéni jellemzőik (nemük és koruk) és foglalkozásuk mennyire hasonlított a közszférában dolgozókéhoz. Azt is vizsgálom, hogy azok a vállalatok, amelyek munkaereje jellemzően közszfératípusú volt, megemelték-e az összes dolgozó bérét vagy sem.

Az elemzés szerint a bérátterjedés mértéke nem volt elhanyagolható: a közszféra-típusú dolgozók bérei 14 százalékkal gyorsabban nőttek a vállalati-típusú dolgozókhoz képest. Azok a dolgozók, akik olyan vállalatnál dolgoztak, amelyben sok dolgozó volt közszféra típusú, hasonló bérnövekményt kaptak függetlenül attól, hogy ők hasonlítottak-e a közszférában dolgozókhoz. Az átterjedési hatás nagy volt a fiataloknál (akik könnyebben váltanak munkát) és a magasan képzetteknél. Az átterjedés hatására azok a vállalatok, amelyek bért kellett hogy emeljenek, valamelyest csökkentették alkalmazottaik számát, valamint kevésbé növelték a szakmunkások bérét (akik jellemzően nem dolgoznak a közszférában).

\footnotetext{
* National Bank of Hungary, Central European University and Institute of Economics, Centre for Economic and Regional Studies - Hungarian Academy of Sciences (CERS-IE). I thank John Sutherland Earle, Péter Elek, Győző Gyöngyösi, Gábor Kézdi, István Kónya, Miklós Koren, János Köllő, Vassilis Monastiriotis, Ágnes Szabó-Morvai and Mirco Tonin for useful advice, John Harbord for editorial assistance and Szilvia Téglás for data cleaning. The data cleaning was executed by Rita Pető, Péter Révész and the Data Sources Department of the CERS-IE. This research was supported by Grant No. 78,255 of the Hungarian Scientific Research Fund. The paper benefited from presentations at the Yearly Conference of the Hungarian Economic Association (2016), the Seminar Series of the CERS-IE Labor Market Group, the Lunch Seminar Series of the CEU Economics Department, the Luis-André Gerard-Varet Conference (2013), the Congress of the European Economic Association (2014), the Conference of the European Association of Labour Economists (2014) and the Conference of Hungarian Labor Economists (Szirák, 2016). The views expressed in this paper are those of the author's and do not necessary reflect the official view of the National Bank of Hungary. All errors are my own.
} 



\section{Introduction}

The interaction of public and corporate wages has largely been neglected by research in past decades, even though public wage spillovers may be an important ingredient of the level and distribution of wages. ${ }^{1}$ If public and private sector workers compete on the same labor market, corporate employees may view the public sector as an alternative to their current employer. When total compensation, including the net value of amenities and disamenities derived from various job attributes, is high in the public sector and there is mobility between the two sectors, private employers have to raise wages to be successful in hiring and reduce high quit rates among incumbent employees. ${ }^{2}$ Such spillovers may affect not only the level of earnings but relative wages as well: employees who facing a high public sector demand and are also willing to become public sector employees will likely experience larger wage spillovers than their colleagues with different skills which are not valued in the public sector. If firms exposed to the public sector do not want to create wage tensions within their workforce, they may want to raise wages for everyone, not only for those exposed to the public sector, which can further increase wage differentials.

Measuring wage spillovers faces many challenges. The typical research design consists of analyzing how the proportion and wages of workers from a "covered" sector (where covered is, for example, minimum wage, foreign ownership or the public sector) alters the wages of uncovered workers with otherwise similar characteristics. ${ }^{3}$ The compensation of workers, however, may be correlated for a multitude of reasons, such as the effects of a common economic background and shocks idiosyncratic to a certain worker-type (Manski, 1993). In addition, the self-selection of workers into one or the other sector which materialize not only along observable, but also unobservable characteristics, makes difficult the comparison of workers of the same marginal productivity (Roy, 1951).

These identification problems are present in the case of public wage spillovers as well. Public sector employees work fewer hours on average, enjoy longer paid vacation, have more secure jobs, and the required effort, worker motivation and job satisfaction may also differ across the two sectors (De Paola et al., 2014; Delfgaauw and Dur, 2008; Dixit, 2002; Heywood et al., 2002; Luechinger et al., 2010). Workers self-select themselves into one or the other sector based on their innate ability, degree of risk aversion, willingness to work hard in exchange for higher wages and faster promotions, characteristics which are all unobserved by researchers (Borjas, 2003a). ${ }^{4}$ Public sector workers cluster in few industries - predominantly in state

\footnotetext{
${ }^{1}$ See Burdett (2012) for a formal model of public wage spillovers. A thorough review of the literature revealed only one paper analyzing public wage spillovers with individual data from the U.S. (Jacobsen, 1992) while Lacroix and Dussault (1984) estimate the spillover effect on a dataset covering Canadian wage agreements. Another strand of literature uses macro data to study whether the government is wage leader, or simply follows the wage setting in the private sector (e.g. Demekas and Kontolemis, 2000; Lamo et al., 2012).

${ }^{2}$ Cahuc et al. (2006) model on-the-job search by assuming that this is a three-way bargaining between the employee, the current employer and an alternative employer (the public sector in the present case), who makes an outside offer.

3 The effect of minimum wage levels on higher earnings was studied by, e.g., Lee (1999) and Neumark et al. (2004), the interaction between foreign and domestically-owned enterprises' wage setting by Aitken et al. (1996), Barry at el. (2005) and Driffield and Girma (2003) and inter-industrial and inter-occupational spillovers by Black et al. (2005) and Latreille and Manning (2000).

${ }^{4}$ These differences also materialize in diverse wage levels in the two sectors (e.g., Christofides and Pashardes, 2002; Gregory and Borland, 1999; Mizala et al., 2011; Tansel, 2005). Other reasons of different wage levels are divergent wage setting mechanisms, such as less frequently used incentive payment schemes in the public sector (Corneo and Rob, 2003),
} 
administration, health care and education - where the share of corporations is small or zero. This makes controlling for industry wage effects cumbersome, although these may be sizable (e.g., Krueger and Summers, 1988). In addition, workers whose characteristics are akin to each other's, tend to have similar wages (or occupy similar positions in the distribution of wages within sector). According to international studies, wage underreporting (Tonin, 2011) affects predominantly the private sector while bribe collection as a source of income (Gorodnichenko and Sabirianova Peter, 2007) is more prevalent in the public sector and thus may also bias the estimation. All these factors create substantial identification problems for the interaction of public and private sector wages.

The Hungarian institutional context is particularly useful for analyzing public wage spillovers as it provides a setting which helps moderating a number of potential biases. In 2002, the government executed a sudden wage increase, changing the public wage premium of public employees (who constitute about 90 percent of public sector workers), from -17 to +7.5 percent from one month to the other. The sizable wage increase improved the outside options for corporate employees: they faced a more attractive alternative to their current job than before and this could induce those who were only marginally attached to the corporate sector to consider changing sector. ${ }^{5}$ The short time frame makes unlikely that other features of the two sectors changed and hence the divergent conditions and worker types in the two sectors will not affect the estimation of wage spillovers, at least not to a large extent.

Besides the quasi-experimental setting, the analysis of public wage spillovers in Hungary can be useful as the public-private wage gap is similar to practically all the Central and East European countries: contrary to the developed or developing countries (see the references in Footnote 4), public sector premium is small or even negative in many countries of the region (Adamchik and Bedi, 2000; European Commission DirectorateGeneral for Economic and Financial Affairs, 2014; Gorodnichenko and Sabirianova Peter, 2007). As the public sector is less attractive in this region than elsewhere, wage spillovers found here can be regarded as a lower bound of this effect.

Using a dataset covering 60 percent of public sector workers and 7 percent of the workforce of Hungarian corporations with at least 5 employees, I use an identification strategy which builds on the methodology used previously in public wage spillover studies (Jacobsen, 1992) and the methods developed for the analysis of the effects of migration on native's wages (Borjas, 2003b). The labor market is segmented by gender, occupation, labor market experience and region, and I proxy the exposure of a corporate worker to the public sector by the share of public sector employment within these labor market segments. To mitigate the bias arising from unobserved characteristics correlated with both earnings and exposure to the public sector, worker-firm joint fixed-effects are included to the regressions. ${ }^{6}$ While it is hard to establish a causal spillover effect, estimating it with the help of a sudden increase in public wages (instead of using only cross sectional

the lobbying of various state-owned agencies (Borjas, 1980), or high public sector wages resulting from vote maximizing of politicians (Shleifer and Vishny, 1994).

${ }^{5}$ Corporate employers may increase wages even if workers do not move, but it is likely that they will be attracted by the higher wage in the public sector. Corneo and Lucifora (1997) and Farber (2005) study threat effects in the context of unionization and Borjas et al. (1997) in the context of international trade.

${ }^{6}$ The data do not have a worker identifier and thus workers cannot be followed in time, but they can be linked across years with the help of their individual characteristics if they stay with the same employer. 
variation) is a step toward this direction. The identifying assumption of this estimation method is that no changes took place in the economy overlapping with the public wage increase that influenced corporate wages and were correlated with the measure of spillover. While I cannot rule out the existence of such event, the short time frame of the public wage increase makes it unlikely to happen. ${ }^{7}$

As wages are determined at the firm level and there is ample evidence that the earnings of workers are correlated within firm (Abowd, Kramarz and Margolis, 1999; Gruetter and Lalive, 2009), an interesting question is how the public wage increase changes corporate wage policies. Employers can react in a multiplicity of ways to the improved outside options of workers. They may raise the wages of those workers only who are exposed to the public sector and thus are at the risk of quitting the firm. This policy, however, will change the distribution of wages within the firm, which will result in tensions, as workers not exposed to the public sector will experience their wages falling relative to those who are of public sector type. To avoid such problems which may materialize in declining productivity or even separations as a result of dissatisfaction, employers can increase the wages of all their workforce. To analyze firms' reaction to the wage increase, I construct a variable measuring the overall exposure of the company to the public sector (which equals to the average value of individual exposures) and I use this in the regressions as the variable of interest.

In the remaining part of the paper I study the heterogeneity of the spillover effect by individual characteristics and also look for channels through which the spillover materializes in corporations. I find that males, young workers and those in occupation groups which are abundant in the public sector experience the largest spillovers. Contrary to this finding, skilled manual workers (the least common occupation group in the public sector) have their wages decline in firms which are exposed to the public sector. It seems thus, that the inequality arising from public sector spillovers are magnified as firms make efforts to control their soaring total wage cost and reduce (or not increase, to say at least) the wages of workers unexposed to the public sector.

The data allow checking two channels through which employers raise wages: the increase of the starting wages of newly hired workers and the differential increase of regular monthly wages and irregular bonuses. As newly hired workers search for a job anyway and do not have firm-specific human capital, it is less costly, and thus more probable, that they choose a job in the public sector. Regarding the differences between the regular wage and bonuses, if firms expect long-term effects, they will probably raise the regular wage but if they want to keep the option to cut back the wage in the future, they rather want to increase the irregular bonuses, as this part of the wage is easier to take away.

A drawback of the method is that the public wage increase can create general equilibrium effects: the inflow of additional funds to the economy may increase the demand for certain goods and services, which creates additional demand for workers in some industries which will result in wage increases (Faggio and Overman, 2014). This type of spillover, however, should lead to differential wage increases by industry and not by worker type. To mitigate such effects, all the regressions have a set of industrial controls. As I compare exposed and not exposed individuals working in the same industry, the general equilibrium effects are

\footnotetext{
7 The high public sector wage may increase the share of public sector workers, which can lead to increased wages in corporations through wage pressures. To eliminate the effect of this endogenous change, I instrument the share of public sector workers with its past values. It should be noted, however, that this is actually one of the mechanisms transmitting the spillover effect.
} 
partialled out with the condition that the composition of workers does not change within industry. As a robustness check, I also run the regression on the sample of firms that export at least 50 percent of their output. These firms are less affected by the increase in the product demand on the domestic markets so they are partially sheltered from such general equilibrium effects. ${ }^{8}$

The main difficulty of this estimation method is that it cannot control for the effects of an event which overlaps in time with the public wage increase and it influences the wages of corporate workers who are of public sector type. While it is not possible to rule out such an event, I estimate how corporate wages change of two worker-types which are present in large proportions in the public sector: females and workers in highskilled occupations. The estimations show only small changes in the gender wage gap and skill premium around the public wage increase, providing indirect evidence that changes in the wage structure (other than the public wage increase) did not contribute much to the increase of corporate wages of workers similar to public sector employees.

Below, I present the data used in the analysis, followed by a description of the public and corporate labor markets. In Section 4 and 5 I describe the methodology and present the results. The last section concludes.

\footnotetext{
${ }^{8}$ Such firms can nevertheless be affected indirectly: if wages increase overall, they also have to comply with the new wage
} levels. 


\section{Data Description}

The dataset used in this study is the Hungarian Wage Survey Data, hosted by the National Employment Office. It provides yearly information on workers' year of birth, gender, occupation, earnings (disaggregated into regular pay and irregular bonuses), type of contract (corporate and several types of public sector labor relations, as discussed below) and whether the worker was hired during the last year. The data are recorded for May of each year. I use the years between 1998 and 2006 in this paper. I augment these data with information on net migration at the county level from the T-Star database which provides information on each Hungarian settlement.

The sampling procedure of corporate employees is based on firm size. Firms with at least 20 employees have to report on those who were born on given days of any month (2 days for production workers, 3 for non-production workers). These data are supplemented with a random sample of smaller firms, with all their employees sampled. In 1998 and 1999 employers with 11-19 workers were sampled while for the latter years the sampling threshold was reduced to firms with 5 employees. Starting with 2002, firms with employment size below 50 were required to provide information on all their employees. ${ }^{9}$

Most public sector organizations use a centralized accounting system, and the data provide information on all of their employees; for the units which did not use the centralized system, the sampling procedure is identical to that used in corporations. ${ }^{10}$ These data include information on the employees of the organizations which are directly subordinated to ministries or the local administration, which are typically schools, hospitals and units of the state administration. The workforce of state-owned enterprises is subject to the corporate labor law and they are included in the corporate sample. The public sector workforce consists of several types of employees. Public employees constitute the bulk of public sector workers (about 85 percent), as most of the workforce in state administration, public healthcare and education work under this labor contract. This is the group which received the wage increase and I keep in the data only this public sector labor type. $^{11}$

The data provide information on the number of production and non-production workers for each firm/public sector organization, thus permitting the construction of weights to correct for the sampling differences of production and non-production workers within firms/organizations. To correct for the different sampling in the public and corporate sectors and to weight the data up to the level of the national economy, I use the total number of public and corporate employees (Hungarian Statistical Office website) from which I subtract the categories not present in the data (the judiciary and the professional police, border guards and the army in the public sector, and enterprises with less than 5 employees from the corporate data). To correct for

\footnotetext{
9 The corporate data contain 30,393 firms. The average number of firm-years is 3. 8,189 firms are present for at least 4, and 4,248 for at least 6 years. Dropping firms with fewer than 11 employees and thus making the sample consistent across years does not affect the results.

${ }^{10}$ Attempts to identify the types of organizations using the centralized accounting system did not uncover any regularity.

11 The data do not provide information on the police, the military, firefighters and border guards. I excluded the employees of courthouses ( 0.25 percent of all public sector employees) as their employment relations are subject to a special law, and did not receive the wage increase. For the same reason, civil servants are also excluded (they make up about 15 percent of the public sector and are typically managers working in state administration, but a few organizations have all their employment with at least a high school degree in this group). If the latter group is included to the sample, the results of the analysis do not change qualitatively.
} 
the different sampling by firm size in the corporate sector, I use the National Tax Authority dataset which contain all double-entry book keeping enterprises.

Workers do not have a unique identifier but with the help of their time invariant characteristics they can be linked across years unless they switch employer. I can follow 206,526 corporate workers for at least two years and 81,190 thousand workers for 3 or more years. To regain the random sample of workers, I constructed individual weights based on the proportion of the workers included in the linked sample.

The dataset was cleaned thoroughly. Categorical variables were harmonized across years, the weights representing the total number of production and non-production workers were cleaned by checking for large jumps between adjacent years, and several observations with very high wages were deleted. I keep in the final sample only full time employees between 16 and 60 years. As Table 1 shows, the final data include 106-153 thousand corporate workers and 305-380 thousand public sector employees each year which make a random sample of about 7 and 52-64 percent of the corresponding populations. 


\section{Employment and Wages in the Public and Corporate Sectors}

\subsection{Composition of Public and Corporate Employment}

The descriptive statistics of public and corporate employment for the pooled sample are presented in Table 2. Overall, one-quarter of the workers in the sample work for the public sector, but this proportion varies widely across individual characteristics. Three-quarters of public sector workers are female, which is almost twice as large a share as in corporations. Corporate employees' potential labor market experience (computed as age-years of education-6) is shorter by two years. Given the peculiar industrial structure of the public sector, it is not surprising that the occupational distribution of employees is very divergent in the two sectors. Professionals and associate professionals are the most typical workers in the public sector: 58 percent of all employees work in such occupations, which is in sharp contrast with such occupations' share of 20 percent in corporations. As expected, skilled workers are the most typical employees in the corporate sector with a share of 46 percent, compared to only 6 percent in the public sphere. Managers' share in the corporate sector is 10 percent, 1.5 percentage points higher than in the public sector. Elementary occupations have a share of 15 percent in the public sector, almost twice as high as in corporations. Finally, the proportion of employees hired during the precedent calendar year is 9 percent in the public sector and 13 percent in corporations.

Public employment varies by region as well. The mean (standard deviation) across the 19 counties and the capital city of the share of public employment is $0.25(0.046)$, with minimum and maximum values of 0.18 and 0.34 , respectively (not presented in the table). It is interesting that public sector employees do not concentrate in the capital city, where the mean public share is very close to the country mean.

\subsection{Wage Policies}

The period between 1998 and 2006 is characterized by a steady growth of the Hungarian economy. Gross domestic product (GDP) grew each year between 3 and 5 percent (Hungarian Statistical Office), and private wages followed this pattern, as documented below. Public sector wages, however, presented a more volatile behavior, shaped by both the need to increase them relative to corporate wages and political considerations.

Wages in the public sector are determined by a wage grid, which consists of a base wage and multipliers. This grid has 10 salary classes and within each class 14 categories, which roughly correspond to the level of education and labor market experience of workers. Total compensation can be larger than specified by the wage grid if the worker receives allowances (such as language and managerial allowances), and public sector organizations are also entitled to paying a higher wage if they have the necessary resources - these materialize in the form of regular extraordinary payments and irregular bonuses. Public sector employees also received a $13^{\text {th }}$ month salary equal to their base wage during the period studied.

The total compensation of all types of public sector employees lagged behind the corporate sector at the turn of the century, and the government made attempts to decrease the gap, at least for some types of employees. In 2001 the wages of civil servants were increased such that the raw gap between them and 
corporate workers declined by about 15 percent. ${ }^{12}$ Public employees' earnings, however, were increased only to the extent to keeping their wages stable relative to corporate earnings between 1998 and 2002. Low average wages, however, put pressure on governments to increase their compensation and in the election campaign in early 2002 the raise of public wages was a major theme. Despite the political discourse, nobody expected that public employees will get a radical wage increase from one day to the next, but after the elections a political scandal erupted, which almost led to the breakup of the newly elected coalition. To restore credibility and perhaps to increase its popularity, the government announced in June that each public employee's base wage will increase by 50 percent in September (according to our data, the base wage was about 85 percent of total compensation in the public sector). ${ }^{13}$ During the following years public sector wages stagnated with some increase in the last year of the analysis.

\subsection{The Evolution of Wages and Employment}

The wage measure used in this paper is the monthly wage paid in May, and it includes the base wage, overtime pay, regular payments other than the base wage, and one twelfth of the previous year's irregular payments (e.g., end-of-year bonuses and the 13 months' salary in the public sector). The first panel of Figure 1 presents the wage levels in the two sectors, deflated by the consumer price index. Throughout the period studied, corporate real wages increased steadily by 1.3-5.3 percent each year, except in 2002 when they hit a record growth of 8.8 percent and in 2004 when they stagnated. Wages in the public sector followed a distinctly different pattern. During the first four years of the analysis the two sectors have comparable growth rates which maintained a 20-22 percent public sector penalty, despite the higher share of high skilled employees. 2002 was election year and this was manifested in the public sector wages, which increased by over 13 percent (but in this year corporate wages also hit a record increase of over 5 percent). This is followed by an increase of 34.5 percent of the total compensation in real terms in 2002, which is more than eight times larger growth rate than of corporate compensation. ${ }^{14}$ In the years after the large wage increase, public wages declined in the public sector by 1-2 percent and increased by 6 percent in 2006 (which was election year again).

The effect of the public sector wage increase on the relative wages between the two sectors was enormous, as the right panel of Figure 1 demonstrates. Between 1998 and 2002 public wages were lower by 17-22 percent relative to corporations, which jumped to a premium of 7.4 percent between 2002 and 2003 . In the subsequent period, relative wages decreased somewhat and increased again. Disaggregation by gender, experience and occupations (available upon request) reveals that females, young workers, and the highly educated had lower relative wages than employees with the opposite characteristics. It is worth noting that a

\footnotetext{
12 This type of public sector employment is not included in the analysis. As discussed in the previous section, they make up 12-15 percent of the public sector and they work mostly in managerial occupations. Including them in the analysis does not change the results.

${ }^{13}$ The fact that the wage increase was announced in June and came to effect in September may raise concerns as corporate employers had the time to increase wages in order to keep their workers. Our yearly data, however, are from May so they cannot be affected by the announcement of the wage increase. If corporations increased wages before September, the analysis will simply associate this increase as part of the spillover effect.

14 The wage policy of 2002 was labeled as a 50 percent increase, but it referred only to the base nominal wages. The growth of nominal base wages for public employees between 2002 and 2003 is indeed very close to 50 percent.
} 
public wage penalty in the public sector for some worker types should not impede wage spillovers from the public to the private sector: the outside opportunities for the worker marginally attached to the private sector suddenly increased, which could induce them to consider switching sector even if wages were still lower in the public sphere.

Employment in the public sector also reacted to the widely changing public sector wage premium. As Figure 2 shows, public sector employment fell before the large wage increase, reaching its minimum in 2000 when it was 6.3 percent lower than in 1998. In the following year the employment size of the sector increased for several years but in the last period of the analysis it contracted again, suggesting that the government reacted to the large cost increase which put a burden on the state budget. This pattern is consistent with early estimates of labor demand elasticities in the public sector, which tend to be negative, but inelastic (as summarized by Ehrenberg and Schwartz, 1983). Corporate employment, after an increase in the first year of the analysis, stagnated until 2003 and increased thereafter by about 4 percent.

\section{Identification Strategy}

Following Jacobsen (1992), I identify public wage spillovers by measuring the correlation between corporate wages and the share of public sector within occupational categories. The present analysis builds on, but also extends this approach by borrowing from the literature on the effects of migration on native workers' wages (Borjas, 2003b) by taking into account work experience and region as well. It also segments the labor market by gender, as the descriptive statistics presented in Table 2 above demonstrate that the share of females is high in the public sector. Finally, it also takes into account the geographical variation in the share of public sector workers. More precisely, I segment the labor market by gender, potential labor market experience (0-10 years, 11-25 year and more than 25 years), 7 occupational dummies (as shown in Table 2) and 21 regions (20 counties and the capital city). This results in 882 labor market segments each year. ${ }^{15}$ The variable used to proxy for the exposure (or similarity) of a corporate worker to the public sector is Psharelnd ${ }_{j t}$, representing the proportion of public sector workers within labor market cell $j$ in year $t$ :

$$
\text { Psharelnd }_{j t}=M_{j t} /\left(M_{j t}+N_{j t}\right) \text {, }
$$

where $M_{j t}$ and $N_{j t}$ are the number of public and corporate workers in gender-experience-occupation-regionyear segments.

With the help of Psharelnd ${ }_{j t}$, I compute a firm's average public sector exposure, PshareFirm ${ }_{t}$, which equals the average of Psharelnd ${ }_{j t}$ :

$$
\text { PshareFirm }_{t}=\sum \text { Psharelnd }_{j t} / \mathrm{N}
$$

where $\mathrm{N}$ equals the number of workers in the firm.

Psharelnd $_{j t}$ can be used as a proxy for public wage spillover if it satisfies several conditions. First and most important, employees of the same gender, labor market experience and occupation need to be close substitutes, regardless of their sector (public or corporations). Second, the net demand for public sector

\footnotetext{
15 We use broad occupational categories rather than education as this variable captures the specific human capital of different occupations to a greater extent.
} 
workers has to be an increasing function in Pshare (the larger net demand is, the more likely someone can get a job, so firms have to increase wages for workers in sectors with high Pshare). The demand for the public sector is clearly increasing in Pshare as this variable is partially based on the occupational distribution of public sector jobs. If this demand condition holds, for the supply side it is enough to assume that there are corporate workers who are willing to work in the public sector but the relatively small wages hitherto prevented them to do so: for example, some workers would be willing to trade higher corporate wages for safer jobs under the new conditions, but before the wage increase they could not afford to switch to the public sector. Even in the unlikely situation where the willingness to switch to the public sector is distributed equally across corporate workers, the varying demand for worker types will make the spillover effect vary with Pshare. If workers facing high public sector demand are also more likely to be "public sector types," then the spillover effects strengthen. For example, females may be more likely to appreciate the less competitive public sector employment which allows them to devote more time to family related activities.

In the baseline specification I regress the log of corporate wages on Psharelnd and PshareFirm interacted with a dummy variable representing the period after the public wage increase (2003-2006). The coefficient associated with this interaction term measures the effect of the share of public workers within a labor market segment on corporate wages around the public wage increase. To control for average wages by worker type, I include fixed effects of the variables used in the construction of Psharelnd (gender, experience, occupation and county). The level of public sector wages may also affect the strength of the spillover and I also control for the average public sector wage within labor market cells $\left(w p_{j t}\right)$. In addition, I also include the net migration at the county level (Netmigration ${ }_{j t}$ ) in order to control for changes in labor supply.

The regression also has year effects and a full set of two-digit industries to control for country- and industry-specific shocks and industrial wage differentials. Industry controls are also useful to control - albeit partially - for general equilibrium effects of the public wage increase itself, such as increases of demand for the product of certain industries which can foster wage increases in that sector. ${ }^{16}$

The estimation equation is the following:

$$
\begin{gathered}
\log \left(w_{i j k t}\right)=\alpha_{0}+\gamma \text { PshareX }_{k t} \text { After }_{t}+\alpha_{w p} \log \left(w p_{k t}\right)+\alpha_{n m} \text { Netmigration }_{j t}+ \\
\alpha_{x} X_{i j k t}+\text { Industry }_{j t}+\text { Year }_{t}+u_{i j k t,}
\end{gathered}
$$

where $i$ indexes workers, $j$ indexes firms, $k$ indexes the labor market segment, $t$ indexes year and the regression is weighted by population weights. The spillover effect is measured by the coefficient $\gamma$ of the interaction term between PshareX ( $X=$ Individual, Firm or a vector composed of Individual and Firm) and the period after the wage increase. In another set of regressions, I interact PshareX with a full set of year dummies to assess the dynamics of the spillover effect.

A first problem of the estimation of spillovers is that some firms employ a higher proportion of public type workers and wages also tend to vary by employer. If firms with a high share of workers exposed to the public sector also raise wages faster than the average corporation, the correlation between wages and PshareX

16 If wage differentials do not change within industry for other reasons than the spillover, these effects can completely account for these general equilibrium effects as the regression compares exposed and not exposed workers within the same industry. 
will be spurious. The change in the composition of corporate workers may also contaminate the estimates if it is correlated with PshareX. If, for example, the least productive corporate workers moved to the public sector or lost their job (and their productivity is not captured by observables) the results may be biased, as the regression compares different workers before and after the wage increase. To attenuate these biases, I add worker-firm fixed effects, which partial out the effect of unobservable worker and firm characteristics that do not change in time (in this case the spillover effect is identified over those workers who are observed both before and after the wage increase and stay with the same firm). This is my preferred specification as arguably decreases the potential biases to the largest extent. ${ }^{17}$ To reduce the bias of the estimated standard errors arising from the correlation of the error terms within worker-type (Moulton, 1990), I correct for clustering at the worker level.

This estimation method reduces the sample approximately by half as the worker identifiers across years can be constructed only for those who were with the same firm for two adjacent years (as described in the data section). In addition, the specification with worker-firm joint effects identifies the spillover effect only on workers who are with the firm both in the period pre- and post-treatment: hence, new entrants to the firm do not contribute to the estimation. To compare the results to the full sample, I also run regressions with firmfixed effects.

The inclusion of these firm and worker-firm fixed-effects is also useful to control for non-pecuniary benefits, which contribute to the overall compensation but are not embedded in the wage variable (as long as they vary from firm to firm). In addition, they also control for the variation of the sample of firms from one year to the next.

The share of public sector workers (the variable of interest) can itself be affected by the public sector wage increase. I argue, however, that this is not a bias but a channel through which spillover materialize: increasing the wage in the public sector creates extra supply for public sector jobs which may increase the share of public sector workers. The increase of the number of jobs in the public sector will put extra pressure on corporations to raise wages in order to keep workers, which is the very mechanism of the spillover effect. Nevertheless, as a robustness check I use the share of public sector workers in 1995 to instrument the contemporaneous public sector share.

I also run two robustness checks. First, to test for a possible contamination of general equilibrium effects, I run the regression only on companies which export at least 50 percent of their output as the activity this group is less likely to be affected by increasing demand from the population. Second, workers of similar characteristics but of different gender can be substitutes for many types of jobs. In order to test whether the estimated effect survives if the spillover effect is computed without taking gender into account, I compute Psharelnd only by segmenting the labor market by occupation, experience and regions and rerun the regression.

\footnotetext{
17 The identifying assumption is that changes in the business environment (other than the public wage increase) did not increase the relative wages of those workers who have a high exposure to the public sector. In absence of a randomized experiment or a suitable instrument, this possibility unfortunately cannot be adequately controlled for in the analysis.
} 


\section{Results}

\subsection{Estimation of the Average Spillover Effect}

The left panel of Appendix Figure A1 presents the cross sectional distribution of Psharelnd in 2002 by labor market cells (defined by gender, experience, occupation and region). Exposure to the public sector varies widely across individuals: the $25^{\text {th }}$ percentile of this distribution is 8 percent and the $75^{\text {th }}$ percentile is 44 percent. Compared to Psharelnd, the exposure of firms to the public sector has a lower variance, but the mean values of the two variables are very similar, as shown in the right panel of the figure. The evolution of Psharelnd and PshareFirm are presented in Appendix Table A1 in the form of regression coefficients, with the variables being the dependent variable and year dummies the regressors (the omitted year is 1998). In the first year of the analysis the average share of public sector workers is 16.8 percent and it declines by 1 percentage point in the next several years. In 2003 - perhaps as a result of the wage increase - it gains 0.7 percentage points but by the end of the period it falls back to its initial level. Similar to Psharelnd, the firm-level exposure is also rather stable in time, as shown in the right panel of the table.

The evolution of corporate log wages for workers with low and high public sector exposure is presented in Figure 3. The figure presents the time series of the dependent variable in the regression analysis relative to 2002 for workers in labor market sectors with Psharelnd and PshareFirm below and above their median value in the years before the wage increase. The figure reveals that before the public wage increase the earnings of the two groups had very similar growth rates (except for 2000). This changed in 2003, right after the wage increase, and those who were of public sector type had faster growth rates by about 3 log points relative to the stagnating wages of the complementary group.

Next I take a closer look at the relationship between the two variables of interest and the wage growth around the public wage increase, and I plot the change in log wages in the years before and after the public wage increase by the exposure of individuals and firms to the public sector. First I compute the difference between 2002 and 2003 of log average wages for the labor market segments defined by genderexperience-occupation-region, and I plot this change against Psharelnd. I do the same for each firm in the analysis and plot is against PshareFirm and I fit a quadratic function on the points in the figure. As Figure 4 shows, the wage growth from 2002 to 2003 is more pronounced at low levels of Psharelnd while it is almost linear for PshareFirm.

The estimated coefficients from the baseline specifications are presented in Table 3. I present two estimates: with firm fixed effects and with controls for worker-firm joint fixed-effects (the preferred specification). The coefficients of the individual characteristics (not presented but available upon request) are all highly significant with magnitudes in the conventional range. The effect of the average public wage is quite sizable and statistically significantly different from zero. Net migration has a small effect, which is statistically significant only when individual-firm joint effects are included in the specification.

The individual spillover effect, measured by the coefficient of the interaction term between Psharelnd and the After time dummy, is positive and significantly different from zero in all specifications. In the firm fixed-effect specification its magnitude is 0.106 , which drops to 0.07 when individual-firm joint effects are 
accounted for in the regression. ${ }^{18}$ The comparison of the two specifications suggests that corporate employees akin to public sector workers have better unobserved individual characteristics as controlling for them decreases their estimated wage effects.

Since the variable of interest is continuous, it is useful to compute the spillover effect for observations at various percentiles in its distribution to grasp the magnitude of the spillover effect. Between the workers at the $25^{\text {th }}$ and $75^{\text {th }}$ percentile of the distribution of Psharelnd (which equal 0.037 and 0.240 , respectively), the spillover effect measured in the worker-firm joint effects specification, created a wage differential of 1.4 percentage points. As corporate wages grew by 12.5 percent between 2002 and 2006 (the period after the public wage increase), the worker at the $75^{\text {th }}$ percentile of the distribution of Psharelnd experienced 14 percent faster wage growth than the person at the $25^{\text {th }}$ percentile.

As the estimated coefficient is a semi-elasticity, dividing it by the value of the variable of interest we can compute the elasticity of corporate wage increase with respect to the exposure to the public sector. The mean value of Psharelnd is 0.165 and the implied elasticity is $0.42 .{ }^{19}$ A 10 percent increase in the share of public sector workers, therefore, of the same skill and gender, occupational category and region, increases the wages of corporate workers by 4.2 percent.

Somewhat surprisingly, the estimated coefficient associated with PshareFirm is equal to 0.206 and 0.136 in the two specifications, almost twice as large as the coefficient estimated for the individual exposure to the public sector. This result suggests that firms care for wage tensions and raise the wages of everybody, not only of those exposed to the public sector. Despite the larger coefficient, the difference in wage growth of the firm situated at the $25^{\text {th }}$ and $75^{\text {th }}$ percentile of the distribution is almost the same (1.7 percent) than what was measured at the individual level as the distribution of PshareFirm is less spread than of Psharelnd. The associated elasticity, however, is larger: as the average firm level Pshare is 0.142, it equals 0.96.

How do our results compare with other studies' findings? Jacobsen (1992) uses individual data from the United State and finds that the share of the public sector in occupations is positively correlated with private sector wages, the estimated effect being between $0.10-0.25$, depending on the gender and race of the studied subpopulation. Lacroix and Dussault (1984) analyze the same question with Canadian data on wage agreements and finds a 4-5 percent spillover effect.

One important difference between these studies and the present analysis is that the public sector usually pays a premium in developed countries which is not the case in Central and Eastern Europe, including Hungary. Wages, however, are not the only factor which workers consider when taking a job: they also account for other amenities and disamenities, like job security, the level of effort, satisfaction with the tasks and so on. The increased wage rate - even if it is still not as large as in corporations - may attract workers if the utility derived from the compensation package (including the above discussed amenities) is larger in the

\footnotetext{
${ }_{18}$ As discussed above, the sample drops to half in the worker-firm joint effects specification. I ran all the firm fixed-effects regressions in Table 3 on the restricted sample and the results do not change, suggesting that the inclusion of the worker effects, and not the sample change drives the differences in the estimated coefficients.

${ }^{19}$ This value is remarkably similar to the magnitude of 0.40 estimate by Borjas (2003b) of the elasticity of native men's wages with respect to the share of immigrants in education-experience cells.
} 
public sector than in corporations. If this is the case, the spillovers may manifest even when the public sector has lower wages even after the large wage increase.

A number of robustness checks is presented in Table 4 (the table presents the results only for the preferred specification for both Psharelnd and PshareFirm). In Panel I restrict the sample only to workers in firms that export at least half of their output, to assess whether general equilibrium effects drive the results. The second panel shows the estimated coefficients of the regression when Psharelnd is constructed without taking gender into account: as males and females are substitutes in a large variety of occupations, it is worth checking whether the results survive when gender is not used in the construction of labor market segments. Finally, in the bottom panel of the table I test whether the results were driven by changes in the share of public sector workers by instrumenting Psharelnd (and implicitly PshareFirm as well) with its values from 1995. As the table demonstrates, the results are remarkably robust to these manipulations, and the estimated spillover effects lie between 0.072 and 0.166 . The sole exception is the instrumental variable regression with PshareFirm, where the estimated coefficient equals 0.92 .

A potential source of endogeneity is that corporate wages increased regardless of the public sector wage jump such that their growth is associated with Pshare, causing therefore a spurious correlation between the two variables. As Pshare is correlated with gender and skill, potential candidates for such effects are changes in the gender wage gap or the skill premium. To test for this possibility, I replace Psharelnd in Equation (2) with a female dummy and a dummy indicating whether the worker has an occupation which requires high skill (professional and associate professional). ${ }^{20}$ The coefficients of these variables are presented in Table A2 and show that the gender wage gap declined only by 1.5 percent and the skill premium increased by 3.2 percent. These changes are pale in comparison to the wage change associated with Psharelnd and they may - at least partially - be caused by the spillover effect itself. While I cannot test formally, these results suggest that the results are not caused by changes in the wages of the groups which are the most exposed to the public sector.

Having established the average spillover effect caused by individual and firm-level exposure to the public sector, I include both Psharelnd and PshareFirm in the same regression to test what is the main driving force of wage spillovers, individual characteristics or firm policy? ${ }^{21}$ As the estimated effects presented in the $3^{\text {rd }}$ and $6^{\text {th }}$ column of Table 3 show, in the firm fixed-effects regressions the individual effect is 0.079 and the firm-level effect is 0.135; in the worker-firm joint effects specification they decline to 0.039 and 0.103 , respectively (the estimated coefficients are statistically significantly different from zero at the 1-percent level). ${ }^{22}$

\footnotetext{
${ }^{20}$ I run these regressions with firm fixed-effects only, as the inclusion of worker effects would take up the increasing experience of the worker during the years of the analysis.

${ }^{21}$ The correlation coefficient between the two variables quite large but not huge (0.53), so it is possible to include them in the same regression and interpret the associated coefficients.

22 A potential problem with this estimation is that in small firms (where we observe few workers), the correlation between Psharelnd and PshareFirm is high, which makes the joint estimation of the two effects problematic. I run the regression on the restricted sample of firm-years with at least 5 worker observations and the coefficient associated with Psharelnd declines and on PshareFirm increases somewhat, but both remain statistically significantly different from zero.
} 
In the next regression I replace the After dummy with a full set of year effects (the omitted year being 2002) and I keep both Psharelnd and PshareFirm in the regression. The estimated effects of this dynamic specification and the 99-percent confidence intervals are visualized in Figure 5 (the coefficients and standard errors are presented in Appendix Table A3). In the period preceding the wage increase (1998-2002) the coefficients vary with no visible time trend; the coefficient in 2002 is quite similar to the one in 1998 for both Psharelnd and PshareFirm (and they are both equal to zero in statistical terms). In 2003, the first year after the public wage increase, the coefficients increase substantially. After this year, the individual exposure effect declines and becomes insignificant but the effect associated with firm exposure continues to increase and becomes as high as 0.140 by 2005 . These results suggest that while individual characteristics are important for wage spillovers, employers do care about wage tensions and increase the wages not only of those who are of public sector type but more generally for their workforce.

How costly was this wage increase for corporations? It is hard to provide a precise measure, but we can compute its approximate cost. Multiplying the average corporate wage in 2002 in each labor market cell by the estimated individual and firm-level spillover effects and the corresponding exposures to the public sector (Psharelnd and PshareFirm), we get an estimate of the total wage cost induced by the public wage increase, which is 4.7 percent of total corporate wage bill in 2002.

How did firms react to this wage increase? Did they shed labor or not? To answer this question, I collapse the data to the firm level and run a regression with log employment as the dependent variable, and PshareFirm interacted with the period after the wage increase as the variable of interest. I control for industry, region, year and firm fixed-effects and the regression is weighted by employment size (the results are not presented in the tables). The estimated coefficient of PshareFirm in the regression is -0.228 , with a standard error of 0.117 , which gives a significance level of 5 percent. This means that employment declined by 3.2 percent in the firm situated at the $75^{\text {th }}$ percentile of the exposure variable's distribution relative to the one at the $25^{\text {th }}$ percentile. While the data cannot provide the reason for the employment decline (a movement along the labor demand curve or the quits of workers who moved to the public sector) they can nevertheless show that an unintended consequence of the public wage increase was the decline of workforce in exposed businesses.

\subsection{Heterogeneity and Channels of the Spillover Effect}

How do worker characteristics affect the spillover effect? In Table 5 we present the estimated coefficients with triple interaction terms between Individual/Firm Pshare, the dummy indicating the period after the wage increase, and a worker attribute (reflecting gender, experience and occupation). To start with gender differences, the total spillover effect, computed as the sum of the estimated coefficients on the firmand individual-level Pshare, is fairly similar across genders ( 0.129 for women and 0.154 for men), but the effect of firm and individual Pshare is very different. While for women the effect equally comes from firm and individual exposure to the public sector, for men only the firm exposure is that matters. A possible explanation of this divergence is that males weight earnings more than other amenities and thus they are less likely to move to the public sector even if the wages in the public sector increase (note that average wages are still 
lower in most labor market segments in the public sector than in corporations even after the wage increase). Thus, male wages are not directly influenced by public sector wages as it is unlikely that they will switch sector. But firms need to raise the wages of females as a consequence of the public wage increase, which will have an indirect effect on males' wages through the wage policy of the firm: employers cannot raise only the wages of females as this would lead to strong wage inequality across genders (at least relative to the status quo) and thus they need to raise the wages of everyone to some extent.

Next we look at the variation of the spillover effect for workers with less than 10, between 11-25 and more than 25 years of labor market experience. The individual spillover effects are positive and significant for each category and they are about 0.09 for young and middle aged, and 0.05 for older workers. The firm level spillover effect is much larger and widely varies by experience. The young group is associated with an effect of 0.29 , the middle aged with 0.13 and the most aged group with a small and statistically insignificant effect. This suggests again that firm, rather than individual level, exposure is that matters in the transmission of wage spillovers. The declining effect by age is most likely caused by employers taking into account in their decision about wages the declining mobility as workers age.

Finally, I analyze the heterogeneity of the spillover effect by broad occupational categories. In this case the individual exposure to the public sector is estimated to have mostly small and statistically insignificant effects in most occupational categories and rather large and negative effects for those who are the least present in the public sector: service and skilled manual workers. Firm-level exposure, on the contrary, has large and positive effects for most occupations: professionals, associate professionals, clerks, managers and service workers all benefit from firm-level spillovers. Skilled workers and those with elementary occupations are associated with small and insignificant effects which may be explained by the low share of skilled workers among public sector workers and by the lack of bargaining power for the least skilled category.

To summarize, the variation of the spillover effect varies by age and occupation and not by gender, suggesting that employers take into account wage pressures in cases when workers execute similar tasks. While it is rather easy to raise the wages of some occupation and experience group while keeping the other group's remuneration fixed, it is much harder to raise wages for women and not of men of similar characteristics as this may lead to wage tensions within the firm. The analysis also shows that firms try to decrease the soaring wage bill by reducing the wages of skilled manual workers, the category who is the least present in the public sector. In addition, they do not increase the wages of the unskilled, who are in large numbers in the public sector but nevertheless are likely to have limited bargaining power.

What are the channels through which public sector wages affect the salaries in corporations? The data allow studying two such channels: new hires versus incumbent workers and regular wages and bonuses. To start with newly hired employees, one possibility is that corporations do not change the wages of incumbent workers, but increase the wage offers for potential new hires. As the latter category is already on the labor market, they can more easily switch to the public sector than incumbents. The data have a variable indicating whether a worker was hired the previous calendar year, and I use this to test whether the starting wage of new hires is related to the exposure of public sector. To do this, I augment the baseline specification with an interaction term between the new hire dummy variable, Psharelnd and PshareFirm and the time dummy 
indicating the period after the wage increase (and I also control for the new hire dummy). The estimated coefficient associated with this triple interaction shows the spillover effect on workers in the year subsequent to their joining the firm. Note that adding individual-firm joint fixed effects to this regression would identify the effect from differences between new hires first year and subsequent years' wages, so I only add firm fixed effects to this regression. I also drop year 2003 from this analysis, as the variable is defined such that the worker was hired in the previous year and thus it is impossible to tell whether the hiring took place before or after the wage increase.

The results of this specification are shown in Table 6. Psharelnd and PshareFirm are both positive and as large as 0.07 and 0.2. The triple interaction term with the individual exposure is positive and equal to 0.04 but this more than offset by the firm-level effect, which equals -0.14 . It seems, therefore, that new hires do not benefit from the public wage increase, at least not in terms of higher starting wages. This suggests that firms are more concerned about keeping their existing workforce and raise the wages of their incumbent employees.

The second channel that I can test is whether corporations plan to raise wages for long term or only temporarily. Remuneration can be increased by raising the regular wage or giving higher bonuses. This may be important as it is much harder to decrease the regular wage than to cut a bonus. To test whether employers planned to raise wages permanently or only temporarily, I decompose the total wage into a regular component (received every month) and an irregular one, which is essentially a bonus. I run three regressions with the same right-hand side but with different dependent variables: the log of the regular monthly wage, a dummy variable indicating whether the worker got a bonus in the previous year and the log of the value of the bonus (conditional on receiving a bonus). ${ }^{23}$ The results are shown in Table 7 . The estimated coefficients of Psharelnd and PshareFirm are 0.035 and 0.082, comparable to the main effects presented above. The proportion of workers receiving a bonus was not affected by individual exposure, but the estimated coefficient associated with firm-level exposure equals 0.176. This is translated to a rather small effect between the workers at the $25^{\text {th }}$ and the $75^{\text {th }}$ percentile of the distribution of PshareFirm (2.2 percentage points). As the unconditional mean value of the dependent variable is 49.5 percent in the regression sample, a higher exposure to the public sector induced employers to increase the frequency of bonuses by 4.4 percent. The effect of the spillover on the value of bonuses (conditional on getting one) is much larger. For the two workers at the $25^{\text {th }}$ and the $75^{\text {th }}$ percentile it increased by 4.4 percent (Psharelnd) and 10.4 percent (PshareFirm). This effect is almost 8 times larger than the effect on regular wages. It seems thus, that firms changed both regular wages and bonuses, but bonuses were raised to a larger extent. On interpretation of this result is that businesses wanted to keep open the possibility to cut back total earnings in the future.

\footnotetext{
23 In the regression sample, 49.5 percent of the workers receive a bonus, which the average value of Huf 20,285, or 10.3 percent of the monthly wage. As the bonus variable is constructed based on the previous year, I drop 2003 from this regression.
} 


\section{Conclusions}

This paper analyzed public wage spillovers, using for identification a sudden and large public sector wage raise which increased the public wage premium from -17 percent to +7.5 percent overnight. The external shock of public wages reduces the potential biases arising when spillovers are estimated only from the cross sectional variation of corporate wages as the specificities of the two sectors do not change around the wage increase. Measuring public sector proximity by the share of public workers within gender, labor market experience, occupation and region and controlling for firm fixed-effect in some, and joint worker-firm effects in other specifications, the paper found that the wage differential induced by the proximity of the public sector induces a 1.4 percentage points faster wage increase between two workers situated at the $25^{\text {th }}$ and the $75^{\text {th }}$ percentile of the distribution of public sector proximity, which corresponds to an elasticity of 0.4 . The analysis also reveals that firms with many workers of public sector type increase the wages of everyone. In this case the elasticity is 0.96 . A dynamic specification of spillovers also suggests that firm exposure is much stronger than individual exposure to the public sector, which plays only a limited role the effect of spillovers. The analysis does not find differences in the level of spillovers by gender, but young workers and in positions requiring a university degree experienced larger spillovers than other groups. The paper also finds that firms raised the wages of their incumbent workforce and not of newly hired workers and that spillovers affected bonuses to a larger extent than regular wages.

Firms reacted to the soaring wage bill in two ways: first, exposed firms to the public sector decreased their labor force by about 3 percent faster than the unexposed ones, and the wages skilled manual workers (who are the least present in the public sector) experienced wage declines in exposed enterprises.

The analysis thus demonstrates that public wage spillover is an important mechanism through which the state intervenes in the labor markets of corporations indirectly, causing their wage costs to raise significantly. In developed countries, where the public sector typically pays a wage premium to its employees, it is possible that spillover effects are larger than what was measured in Hungary, albeit in absence of such a radical public wage policy these effects cannot be quantified. 


\section{References}

Abowd, John M., Francis Kramarz, David N. Margolis. 1999. "High Wage Workers and High Wage Firms." Econometrica 67(2), 251-333.

Adamchik, Vera A., Arjun S. Bedi. 2000. "Wage Differentials between the Public and the Private Sectors: Evidence from an Economy in Transition." Labour Economics 7, 203-224.

Aitken, Brian, Ann Harrison, Robert E. Lipsey. 1996. "Wages and Foreign Ownership. A comparative Study of Mexico, Venezuela, and the United States." Journal of International Economics 40, 345-371.

Barry, Frank, Holger Görg, Eric Strobl. 2005. "Foreign Direct Investment and Wages in Domestic Firms in Ireland: Productivity Spillovers versus Labour-Market Crowding Out." International Journal of Economics and Business 12(1), 67-84.

Black, Dan, Terra McKinnish, Seth Sanders. 2005. "The Economic Impact of the Coal Boom and Bust." Economic Journal 115, 449-476.

Borjas, George J. 1980. "Wage Determination in the Federal Government: The Role of Constituents and Bureaucrats." Journal of Political Economy 88(6), 1110-1147.

Borjas, George J. 2003a. "Wage Structures and the Sorting of Workers into the Public Sector." In For the People: Can we Fix Public Service?, eds. John J. Donahue, Joseph Nye, Washington, D.C.: Brookings Institution Press.

Borjas, George J. 2003b. "The Labor Demand is Downward Sloping: Reexamining the Impact of Immigration on the Labor Market." Quarterly Journal of Economics 118(4), 1335-1374.

Borjas, George J., Richard B. Freeman, Lawrence F. Katz. 1997. "How much do Immigration and Trade Affect Labor Market Outcomes?" Brookings Papers on Economic Activity 1, 1-90.

Burdett, Ken. 2012. "Towards a Theory of the Labor Market with a Public Sector." Labour Economics 19, 68-75.

Cahuc, Pierre, Fabien Postel-Vinay, Jean-Mark Robin. 2006. "Wage Bargaining with on-the-Job Search: Theory and Evidence." Econometrica 74(2), 323-364.

Christofides, Louis N., Panos Pashardes. 2002. "Self/Paid-Employment, Public/Private Sector Selection, and Wage Differentials." Labour Economics 9, 737-762.

Corneo, Giacomo, Claudio Lucifora. 1997. “Wage Formation Under Union Threat Effects: Theory and Empirical Evidence." Labour Economics 4, 265-292.

Corneo, Giacomo, Rafael Robb. 2003. "Working in Public and Private Firms." Journal of Public Economics 87, 1335-1352.

De Paola, Maria, Vincenzo Scoppa, Valeria Puppo. 2014. “Absenteeism in the Public Sector: The Effects of Changes in Sick Leave Policy." Journal of Labor Economics 32(2), 337-360.

Delfgaauw, Josse, Robert Dur. 2008. "Incentives and Workers' Motivation in the Public Sector." Economic Journal 118(525), 171-191.

Demekas, Dimitri G., Zenon G. Kontolemis. 2000. “Government Employment and Wages and Labor Market Performance." Oxford Bulletin of Economics and Statistics 62(3), 391-415.

Dixit, Avinash. 2002. "Incentives and Organization in the Public Sector: An Interpretative Review." Journal of Human Resources 37(4), 696-727.

Driffield, Nigel, Sourafel Girma. 2003. "Regional Foreign Direct Investment and Wage Spillovers: Plant Level Evidence from the UK Electronics Industry." Oxford Bulletin of Economics and Statistics 65(4), 453-474.

Ehrenberg, Ronald G., Joshua L. Schwartz. 1983. “Public Sector Labor Markets.” NBER Working Paper Series No. 1179.

European Commission, Directorate-General for Economic and Financial Affairs. 2014. "Government Wages and Labour Market Outcomes. European Economy Occasional Papers No. 190, http://ec.europa.eu/economy finance/publications/occasional paper/2014/pdf/ocp190 en.pdf. Last accessed 15.12.2016. 
Faggio, Giulia, Henry Overman. 2014. "The Effect of Public Sector Employment on Local Labour Markets." Journal of Urban Economics 79, 91-107.

Farber, Henry S. 2005. "Nonunion Wage Rates and the Threat of Unionization." Industrial and Labor Relations Review 58(3), 335-352.

Gorodnichenko, Yuriy, Klara Sabirianova Peter. 2007. “Public Sector Pay and Corruption: Measuring Bribery from Micro Data." Journal of Public Economics 91, 963-991.

Gregory, Robert G., Jeff Borland. 1999. „Recent Developments in Public Sector Labor Markets.” In Handbook of Labor Economics, eds. Orley Ashenfelter, David Card, vol. 3, Chapter 53, New York: Elsevier.

Gruetter, Max, Rafael Lalive. 2009. "The Importance of Firms in Wage Negotiations." Labour Economics 16, 149-160.

Heywood, John S., W. S. Siebert, Xiangdong Wei. 2002. "Worker Sorting and Job Satisfaction: The Case of Union and Government Jobs." Industrial and Labor Relations Review 55(4), 595-609.

Hungarian Statistical Office, http://www.ksh.hu/?lang=en, accessed September 2014.

Jacobsen, Joyce. 1992. “Spillover Effects from Government Employment." Economics Letters 39, 101-104.

Krueger, Alan B., Lawrence H. Summers 1988. "Efficiency Wages and the Inter-Industrial Wage Structure." Econometrica 56(2), 259-293.

Lacroix, Robert, Francois Dussault. 1984. "The Spillover Effect of Public-Sector Wage Contracts in Canada." Review of Economics and Statistics 66(3), 509-512.

Lamo, Ana, Javier J. Pérez, Ludger Schuknecht. 2012. "Public or Private Wage Leadership? An International Perspective." Scandinavian Journal of Economics 114(1), 228-244.

Latreille, Paul L., Neil Manning. 2000. "Inter-Industry and Inter-Occupational Wage Spillovers in UK Manufacturing." Oxford Bulletin of Economics and Statistics 62(1), 83-99.

Luechinger, Simon, Stepan Meier, Alois Stutzer. 2010. „Why Does Unemployment Hurt the Employed? Evidence from the Life Satisfaction Gap Between the Public and the Private Sector." Journal of Human Resources 45(4), 998-1045.

Mizala, Alejandra, Pilar Romaguera, Sebastian Gallegos. 2011. „Public-Private Wage Gap in Latin America (1992-2007): A Matching Approach." Labour Economics 18, S115-S131.

Moulton, Brent R. 1990. „An Illustration of a Pitfall in Estimating the Effects of Aggregate Variables on Micro Units." Review of Economics and Statistics 72(2), 334-338.

Manski, Charles. 1993. "Identification of Endogenous Social Effects: The Reflection Problem." Review of Economic Studies 60, 531-542.

Roy, Andrew. D. 1951. "Some Thoughts on the Distribution of Earnings." Oxford Economic Papers 3(2), 135-146. Shleifer, Andrei, Robert W. Vishny. 1994. "Politicians and Firms." Quarterly Journal of Economics, 109(4), 9951025.

Tansel, Aysit. 2005. "Public-Private Employment Choice, Wage Differentials, and Gender in Turkey." Economic Development and Cultural Change 53(2), 453-477.

Tonin, Mirco. 2011. "Minimum Wage and Tax Evasion: Theory and Evidence." Journal of Public Economics 95, 1635-1651. 
Tables and Figures

Table 1: Sample Size and Population of Public and Corporate Sectors

\begin{tabular}{cccccc}
\hline & \multicolumn{3}{c}{ Public } & & \multicolumn{2}{c}{ Corporate } \\
\cline { 2 - 3 } \cline { 5 - 6 } Year & Sample & Population & & Sample & Population \\
\hline 1998 & 338.1 & 649.6 & & 105.7 & 1842.0 \\
1999 & 371.7 & 622.7 & & 107.6 & 1890.0 \\
2000 & 366.3 & 608.7 & & 125.7 & 1887.4 \\
2001 & 360.9 & 613.1 & & 125.7 & 1887.8 \\
2002 & 377.9 & 618.8 & & 133.6 & 1871.6 \\
2003 & 404.7 & 631.8 & & 134.7 & 1874.2 \\
2004 & 395.3 & 617.7 & & 148.9 & 1911.2 \\
2005 & 386.3 & 610.2 & & 152.9 & 1922.0 \\
2006 & 379.6 & 593.3 & & 149.2 & 1919.6 \\
\hline
\end{tabular}

Notes: Thousands of workers. The public sector population refers to public employees (the police, military, firefighters and border guards are excluded). The corporate sector population refers to double entry book keeping firms with at least 11 workers in 1998 and 1999, and at least 5 workers thereafter. 
Table 2: Composition of the Workforce in the Public and Corporate Sectors

\begin{tabular}{|c|c|c|}
\hline & Public & Corporate \\
\hline Mean & 24.7 & 75.3 \\
\hline \multicolumn{3}{|l|}{ Gender } \\
\hline Female & 75.1 & 39.7 \\
\hline \multicolumn{3}{|l|}{ Labor market experience } \\
\hline \multirow[t]{2}{*}{ Average experience } & 23.8 & 22.0 \\
\hline & $(10.6)$ & (10.9) \\
\hline \multicolumn{3}{|l|}{ Occupation } \\
\hline Manager & 7.1 & 9.6 \\
\hline Professional & 33.3 & 4.9 \\
\hline Technician, associate professional & 24.4 & 14.9 \\
\hline Clerk & 5.7 & 6.7 \\
\hline Service worker & 7.7 & 10.2 \\
\hline Skilled worker & 6.4 & 45.6 \\
\hline Elementary occupation & 15.3 & 8.1 \\
\hline \multicolumn{3}{|l|}{ New Hire } \\
\hline Hired previous year & 9.3 & 13.4 \\
\hline $\mathrm{N}$ & $3,380,055$ & $1,184,004$ \\
\hline
\end{tabular}


Figure 1: The Evolution of Wages in the Public and Corporate Sectors and the Public Wage Premium

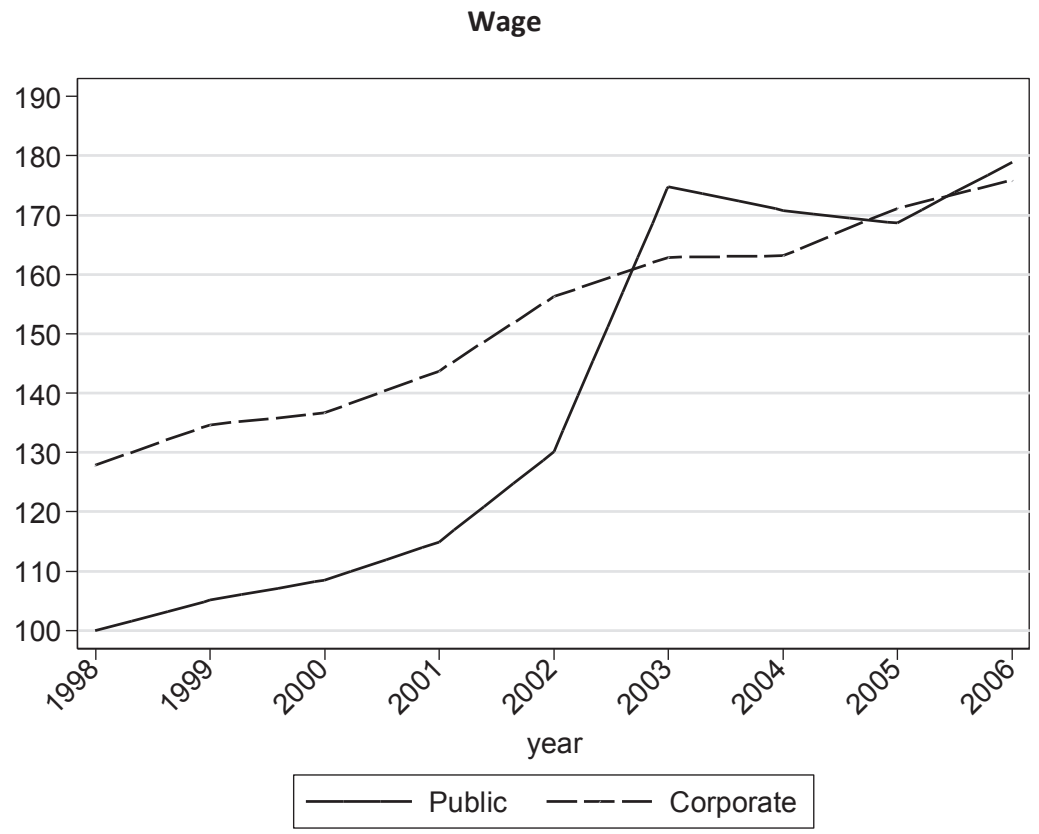

Public Wage Premium

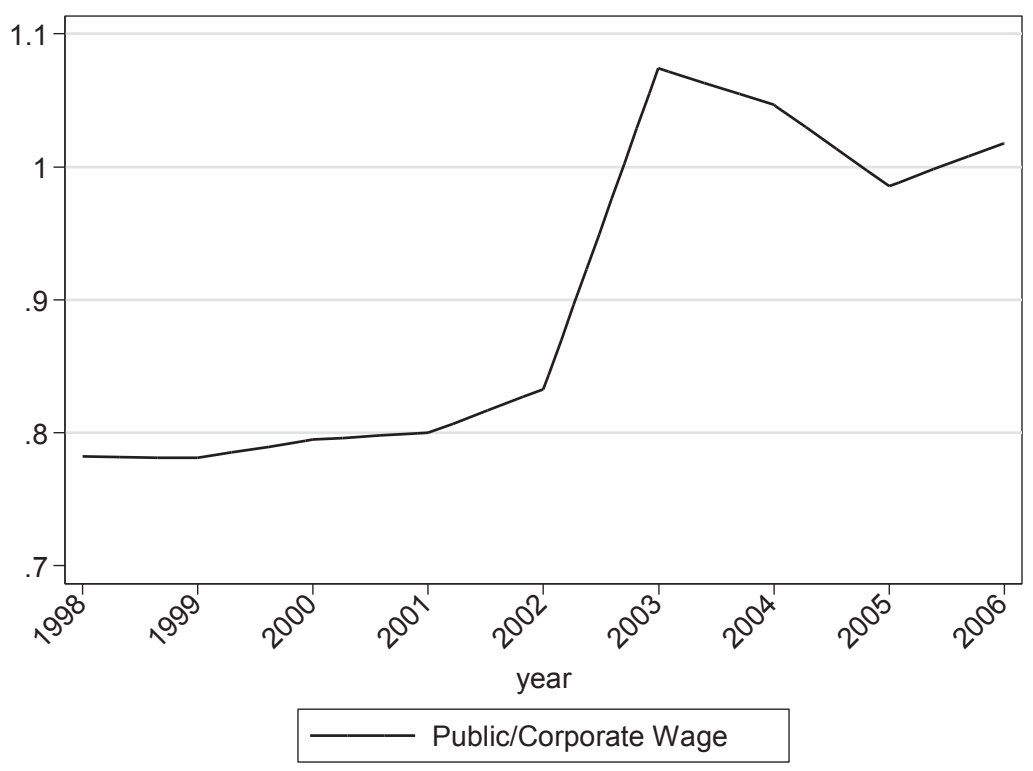

Notes: $\mathrm{N}=3,380,055$ (public sample); 1,184,004 (corporate sample). In the left panel wages are expressed in thousands of 2006 HUF, deflated by the consumer price index. The right panel presents the unconditional ratio of public and corporate average wages. 
Figure 2: Employment Dynamics in the Public and Corporate Sectors

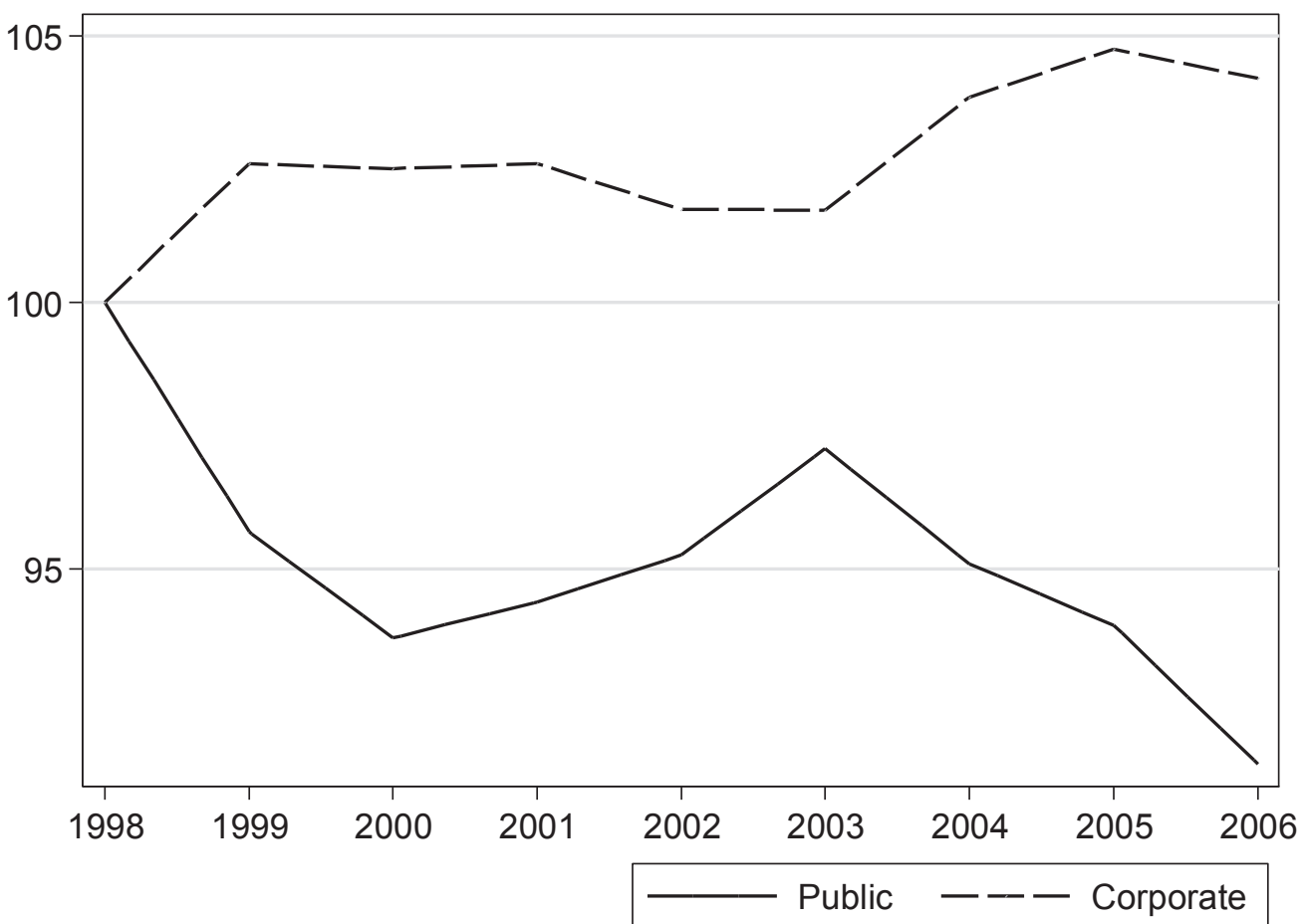

Notes: $\mathrm{N}=3,380,055$ (public sample); 1,184,004 (corporate sample). The figure presents the proportional change relative to 1998 of total employment in the public and corporate sectors. 
Figure 3: Growth of Corporate Wages in Labor Market Segments with Low and High Public Sector Participation

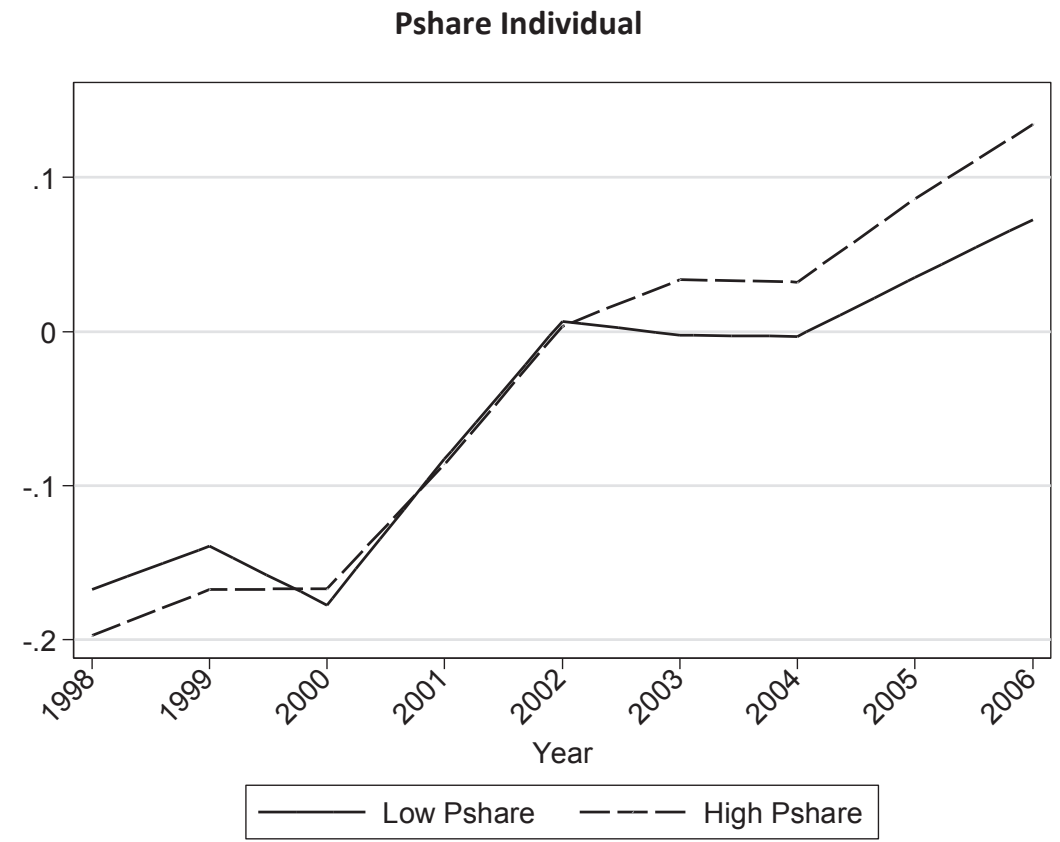

Pshare Firm

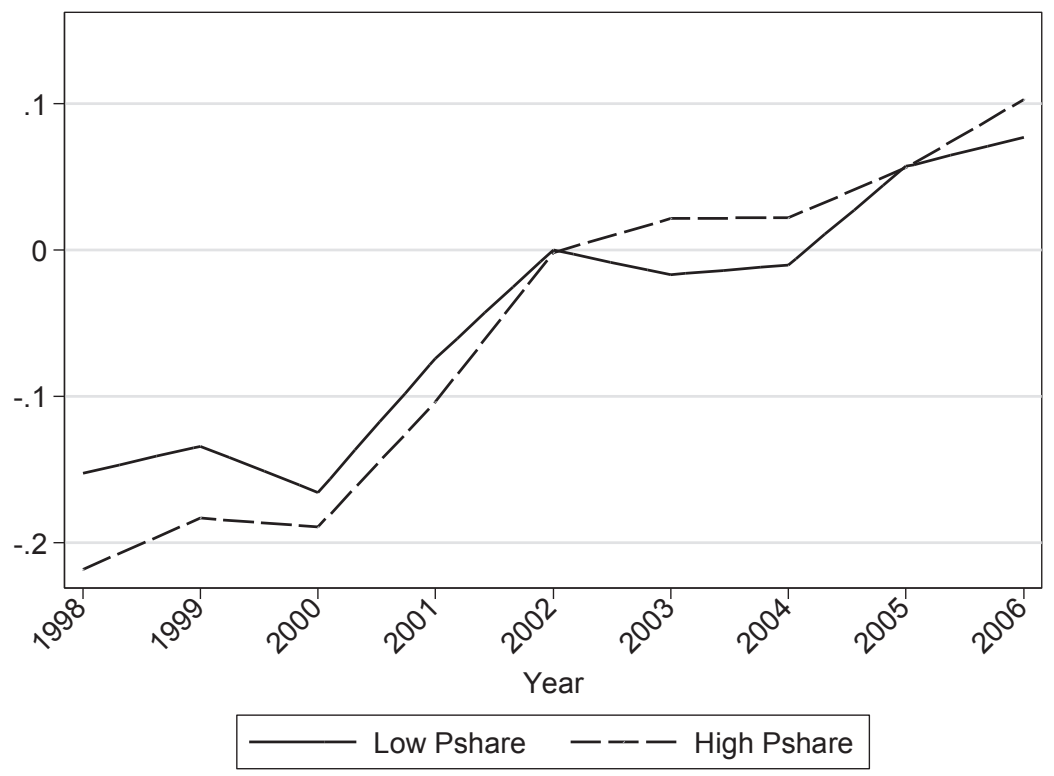

Notes: $N=1,184,004$. The figure presents the evolution of average log corporate wages relative to 2002 of workers in sectors defined by the share of public sector workers in labor market segments defined by gender, labor market experience, occupation and county above and below the median share. 
Figure 4: Growth of Corporate Wages in by Exposure to the Public Sector, 2002-2003

Pshare Individual

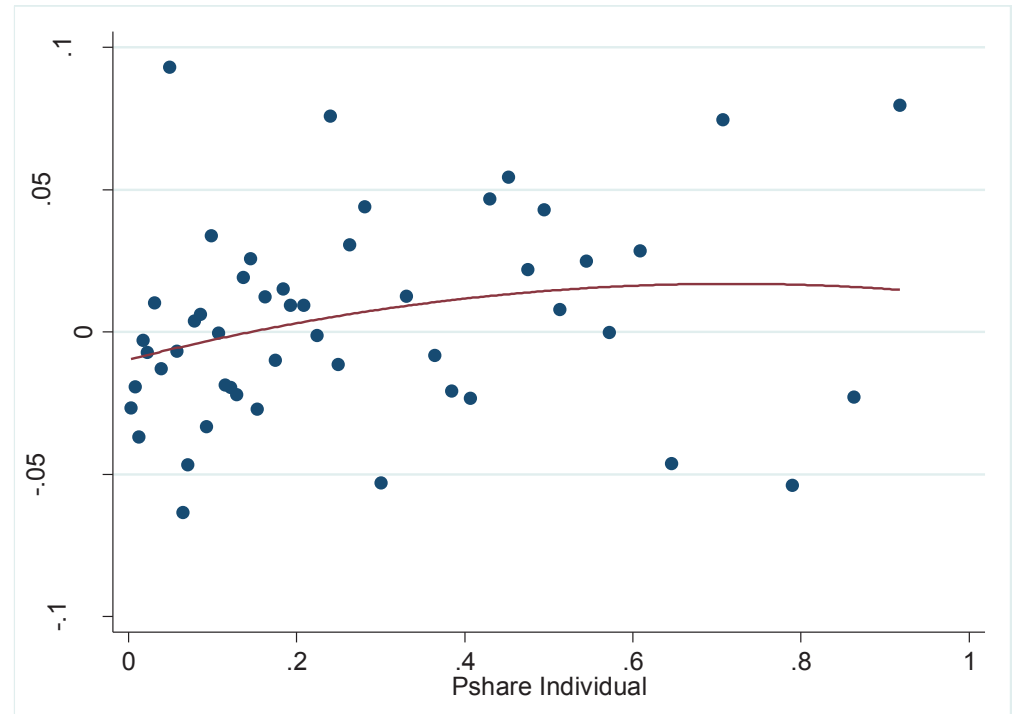

Pshare Firm

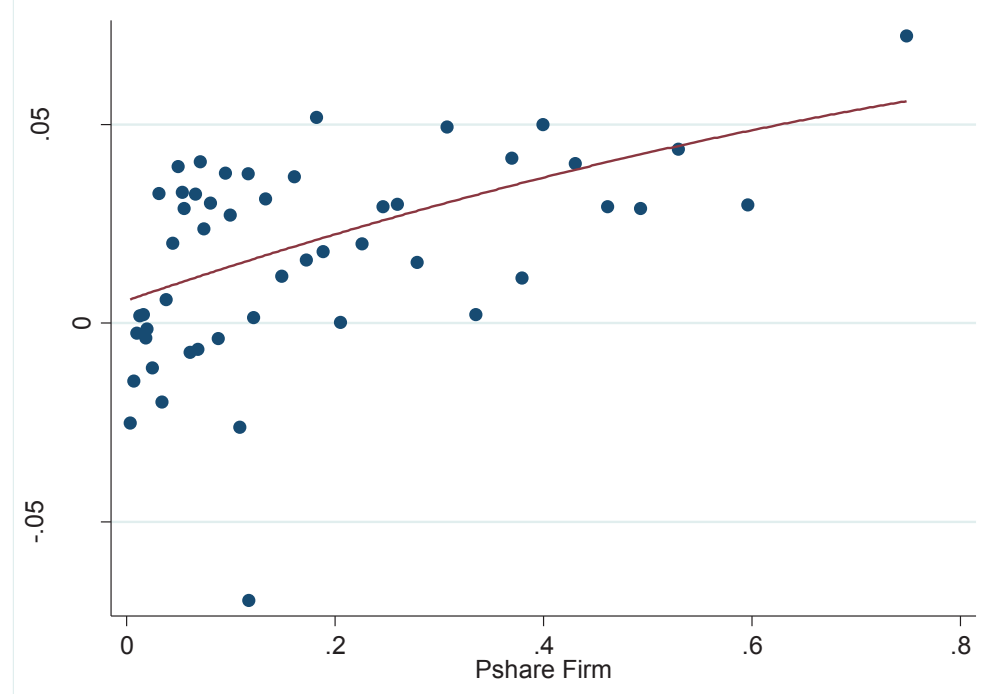

Notes: $N=268,342$. The figure presents the log wage difference between 2002 and 2003 of labor market sectors of gender-occupation-experienceregion (left panel) and of firms (right panel). 
Table 3: The Effect of Public Sector Exposure on Corporate Wages

\begin{tabular}{lcccccc}
\hline & & Firm FE & \multicolumn{3}{c}{ Worker-Firm FE } \\
\hline Pshare Indiv. After & $0.106^{* *}$ & & $0.079^{* *}$ & $0.070^{* *}$ & & $0.039^{* *}$ \\
& $(0.013)$ & & $(0.013)$ & $(0.008)$ & & $0.008)$ \\
Pshare Firm After & & $0.206^{* *}$ & $0.134^{* *}$ & & $0.138^{* *}$ & $0.105^{* *}$ \\
& & $(0.031)$ & $(0.031)$ & & $(0.014)$ & $(0.016)$ \\
\hline Ln(Av. Public Wage) & $0.111^{* *}$ & $0.113^{* *}$ & $0.109^{* *}$ & $0.116^{* *}$ & $0.119^{* *}$ & $0.117^{* *}$ \\
& $(0.016)$ & $(0.017)$ & $(0.017)$ & $(0.010)$ & $(0.010)$ & $(0.010)$ \\
Net Migration*100 & 0.002 & -0.001 & -0.001 & $0.010^{*}$ & $0.010^{*}$ & $0.010^{*}$ \\
& $(0.008)$ & $(0.008)$ & $(0.008)$ & $(0.005)$ & $(0.005)$ & $(0.005)$ \\
\hline$R^{2}$ & 0.734 & 0.734 & 0.734 & 0.931 & 0.934 & 0.934 \\
\hline
\end{tabular}

Notes: $\mathrm{N}=1,183,411$ (Firm FE), 584,313 (Individual-Firm FE). Dependent variable: log wage. "After" = 1 for the years 2003 to 2006. Firm FE = firm fixed effects; Worker-Firm FE = worker-firm joint fixed effects. The Firm FE regression includes controls for gender, experience, occupation and county. Net migration is defined at the county level. Each regression controls for industry and year fixed effects. Standard errors clustered at the firm (worker-firm) level in the Firm FE (Worker-Firm FE) regressions. The regressions are weighted with population weights. ${ }^{* *}=$ significant at the 1 -percent level; $*$ significant at the 5 -percent level. 


\section{Table 4: Robustness Checks}

\begin{tabular}{|c|c|c|}
\hline Variable & Individual & Firm \\
\hline \multicolumn{3}{|c|}{ I. Only Exporting Firms } \\
\hline \multirow[t]{2}{*}{ Pshare After } & $0.080 * *$ & $0.107 * *$ \\
\hline & $(0.019)$ & $(0.043)$ \\
\hline $\mathrm{R}^{2}$ & \multicolumn{2}{|c|}{0.923} \\
\hline $\mathrm{N}$ & \multicolumn{2}{|c|}{92,325} \\
\hline \multicolumn{3}{|c|}{ II. Sectors Constructed without Gender } \\
\hline \multirow[t]{2}{*}{ Pshare After } & $0.072 * *$ & $0.146 * *$ \\
\hline & $(0.008)$ & $(0.015)$ \\
\hline $\mathrm{R}^{2}$ & \multicolumn{2}{|c|}{0.934} \\
\hline $\mathrm{N}$ & \multicolumn{2}{|c|}{584,313} \\
\hline \multicolumn{3}{|c|}{ III. Instrumental Variable: Pshare in 1995} \\
\hline \multirow[t]{2}{*}{ Pshare After } & $0.094 * *$ & $0.920 * *$ \\
\hline & $(0.026)$ & $(0.043)$ \\
\hline $\mathrm{R}^{2}$ & \multicolumn{2}{|c|}{0.433} \\
\hline $\mathrm{N}$ & \multicolumn{2}{|c|}{$1,182,938$} \\
\hline \multicolumn{3}{|c|}{$\begin{array}{l}\text { Notes: Dependent variable: log wage. "After" }=1 \text { for the years } 2003 \text { to } 2006 \text {. The sample in } \\
\text { Panel I consists of those firms which export at least } 50 \text { percent of their output. The coefficient } \\
\text { (standard error) of the instrument in the first stage IV regression is } 0.260(0.002) \text { for Psharelnd, } \\
0.340(0.003) \text { for PshareFirm. Each regression controls for log average public sector wage in the } \\
\text { labor market sector, net migration at the county level, industry and year fixed effects, and } \\
\text { worker-firm joint fixed effects. Standard errors clustered at the worker-firm level. The } \\
\text { regressions are weighted with population weights. }{ }^{* *}=\text { significant at the } 1 \text {-percent level; }{ }^{*}= \\
\text { significant at the 5-percent level. }\end{array}$} \\
\hline
\end{tabular}


Figure 5: Yearly Effect of Public Sector Exposure on Corporate Wages

Pshare Individual

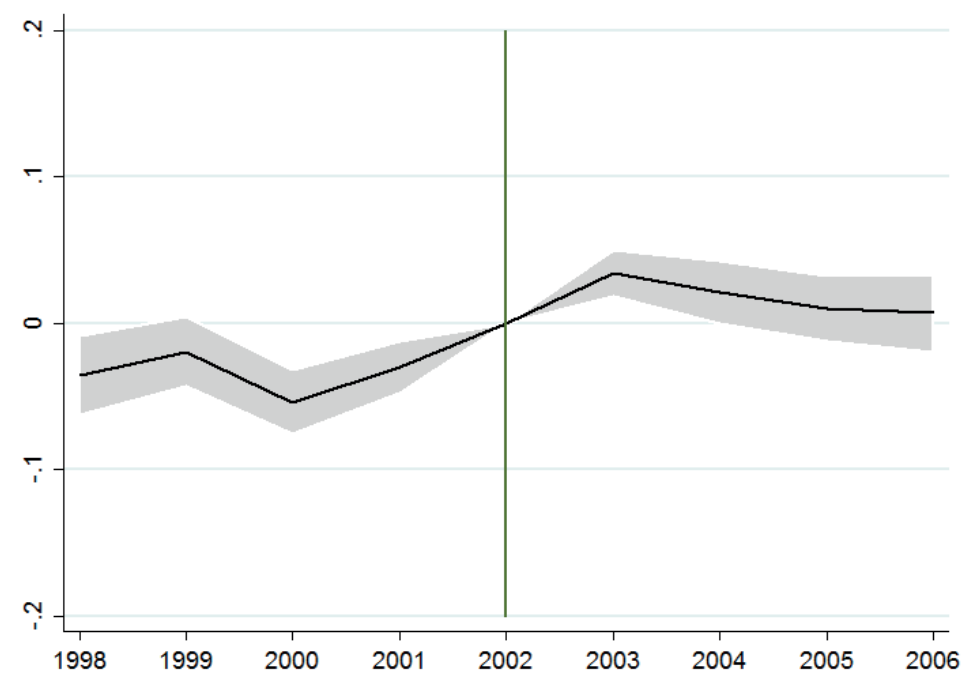

Pshare Firm

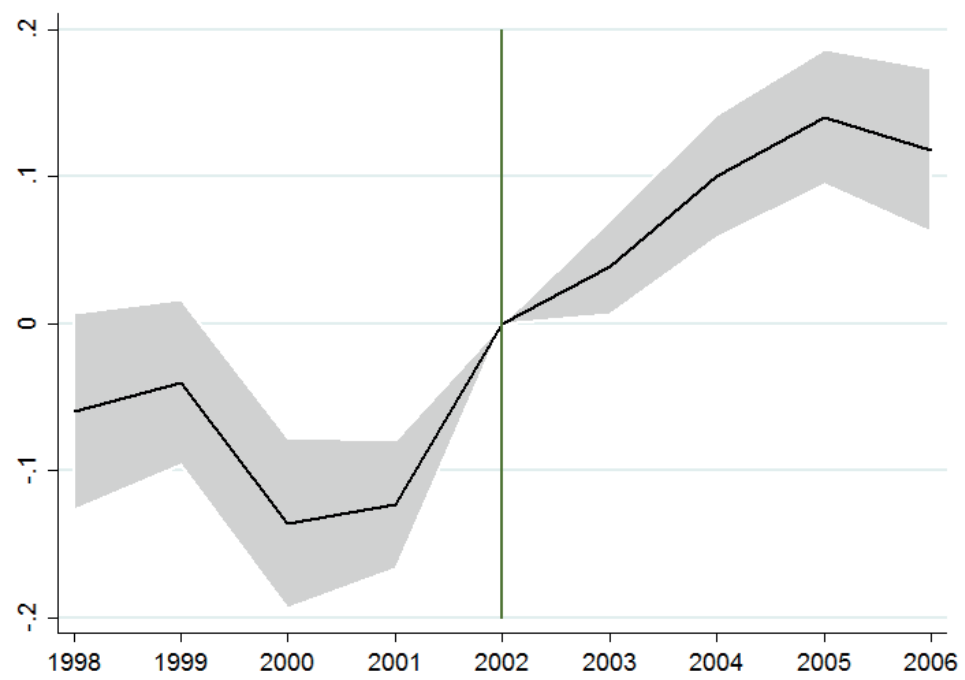

Notes: $N=584,313$. The figure plots the estimated coefficients and the associated 99-percent confidence intervals of Psharelnd and PshareFirm added to the same regression and interacted with years. Dependent variable: $\log$ (wage). The regression controls for log average public sector wage in the labor market sector, net migration at the county level, industry and year fixed effects, and worker-firm joint fixed effects. Standard errors clustered at the worker-firm level. The regression is weighted with population weights. The regression coefficients (standard errors) are presented in Appendix Table A3. 
Table 5: Heterogeneity of the Spillover Effect by Gender, Experience and Occupation

\begin{tabular}{|c|c|c|}
\hline & Pshare Individual After & $\begin{array}{c}\text { Pshare Firm } \\
\text { After }\end{array}$ \\
\hline \multicolumn{3}{|l|}{ Gender } \\
\hline \multirow[t]{2}{*}{ Female } & $0.066 * *$ & $0.063 * *$ \\
\hline & $(0.010)$ & $(0.018)$ \\
\hline \multirow[t]{2}{*}{ Male } & 0.006 & $0.148 * *$ \\
\hline & $(0.018)$ & $(0.021)$ \\
\hline $\mathrm{R}^{2}$ & \multicolumn{2}{|c|}{0.934} \\
\hline \multicolumn{3}{|l|}{ Labor Market Experience } \\
\hline \multirow[t]{2}{*}{ Experience $0-10$ years } & $0.089 * *$ & $0.292 * *$ \\
\hline & $(0.022)$ & $(0.028)$ \\
\hline \multirow[t]{2}{*}{ Experience $11-25$ years } & $0.085^{* *}$ & $0.125^{* *}$ \\
\hline & $(0.012)$ & $(0.020)$ \\
\hline \multirow[t]{2}{*}{ Exp 26- years } & $0.048 * *$ & -0.019 \\
\hline & $(0.010)$ & $(0.019)$ \\
\hline $\mathrm{R}^{2}$ & \multicolumn{2}{|c|}{0.934} \\
\hline \multicolumn{3}{|l|}{ Occupation } \\
\hline \multirow[t]{2}{*}{ Manager } & 0.018 & $0.107 * *$ \\
\hline & $(0.034)$ & $(0.039)$ \\
\hline \multirow[t]{2}{*}{ Professional } & 0.034 & $0.145^{* *}$ \\
\hline & $(0.019)$ & $(0.040)$ \\
\hline \multirow[t]{2}{*}{ Associate Professional } & -0.012 & $0.180 * *$ \\
\hline & $(0.017)$ & $(0.027)$ \\
\hline \multirow[t]{2}{*}{ Clerk } & 0.005 & $0.118^{* *}$ \\
\hline & $(0.025)$ & $(0.035)$ \\
\hline \multirow[t]{2}{*}{ Service worker } & $-0.074 * *$ & $0.102 * *$ \\
\hline & $(0.028)$ & $(0.032)$ \\
\hline \multirow[t]{2}{*}{ Skilled worker } & $-0.423^{* *}$ & 0.043 \\
\hline & $(0.065)$ & $(0.028)$ \\
\hline \multirow[t]{2}{*}{ Elementary } & -0.032 & -0.051 \\
\hline & $(0.026)$ & $(0.043)$ \\
\hline $\mathrm{R}^{2}$ & & \\
\hline
\end{tabular}

Notes: $\mathrm{N}=584,313$. The presented coefficients are triple interactions between Pshare defined at the individual/firm level, the period after the public wage increase and an individual characteristic. The coefficients associated with Psharelnd and PshareFirm come from the same regression in each panel. Dependent variable: log wage. "After" = 1 for the years 2003 to 2006. Each regression controls for log average public sector wage in the labor market sector, net migration at the county level, industry and year fixed effects, and worker-firm joint fixed effects. Standard errors clustered at the worker-firm level. The regressions are weighted with population weights. ${ }^{* *}=$ significant at the 1 -percent level; ${ }^{*}=$ significant at the 5 -percent level. 
Table 6: The Effect of Wage Spillover on Newly Hired Workers

\begin{tabular}{|c|c|}
\hline Variable & Coefficient \\
\hline \multirow{2}{*}{ Pshare After } & $0.068^{* *}$ \\
\hline & $(0.014)$ \\
\hline \multirow[t]{2}{*}{ Pshare After * New Hire } & $0.042 *$ \\
\hline & $(0.017)$ \\
\hline \multirow[t]{2}{*}{ Pshare Firm After } & $0.199 * *$ \\
\hline & $(0.043)$ \\
\hline \multirow[t]{2}{*}{ Pshare Firm After * New Hire } & $-0.137 * *$ \\
\hline & $(0.027)$ \\
\hline \multirow[t]{2}{*}{ New Hire } & $-0.045^{* *}$ \\
\hline & $(0.003)$ \\
\hline $\mathrm{R}^{2}$ & 0.735 \\
\hline $\mathrm{N}$ & $1,048,701$ \\
\hline \multicolumn{2}{|c|}{$\begin{array}{l}\text { Notes: dependent variable: log wage. "After" = } 1 \text { for the years } \\
2004 \text { to } 2006 \text {. The year } 2003 \text { is dropped from the sample. The } \\
\text { regression controls for log average public sector wage in the labor } \\
\text { market sector, net migration at the county level, gender, } \\
\text { experience, occupation, industry and year fixed effects, and firm } \\
\text { fixed-effects. Standard errors clustered at the worker-firm level. } \\
\text { The regressions are weighted with population weights. }{ }^{* *}= \\
\text { significant at the 1-percent level; }{ }^{*}=\text { significant at the } 5 \text {-percent } \\
\text { level. }\end{array}$} \\
\hline
\end{tabular}


Table 7: The Effect of Public Wage Spillovers on Regular Wages and Bonuses

\begin{tabular}{lccc}
\hline & Regular Wage & Bonus Dummy & Value of Bonus \\
\hline Pshare After & $0.035^{* *}$ & 0.007 & $0.175^{* *}$ \\
& $(0.008)$ & $(0.022)$ & $(0.055)$ \\
Pshare Firm After & $0.082^{* *}$ & $0.176^{* *}$ & $0.742^{* *}$ \\
& $(0.015)$ & $(0.046)$ & $(0.116)$ \\
\hline $\mathrm{R}^{2}$ & 0.932 & 0.932 & 0.781 \\
$\mathrm{~N}$ & 584,313 & 515,133 & 256,513 \\
\hline
\end{tabular}

Notes: Dependent variable: log wage. "After" = 1 for the years 2003 to 2006 . The mean value of the bonus dummy is 0.495 . Each regression controls for log average public sector wage in the labor market sector, net migration at the county level, industry and year fixed effects, and worker-firm joint fixed effects. Standard errors clustered at the worker-firm level. The regressions are weighted with population weights. ${ }^{* *}=$ significant at the 1 -percent level; ${ }^{*}=$ significant at the 5 -percent level. 


\section{Appendix}

Figure A1: Public Sector Employment Share in

Gender-Experience-Occupation-County Segments of the Labor Market

\section{Worker}

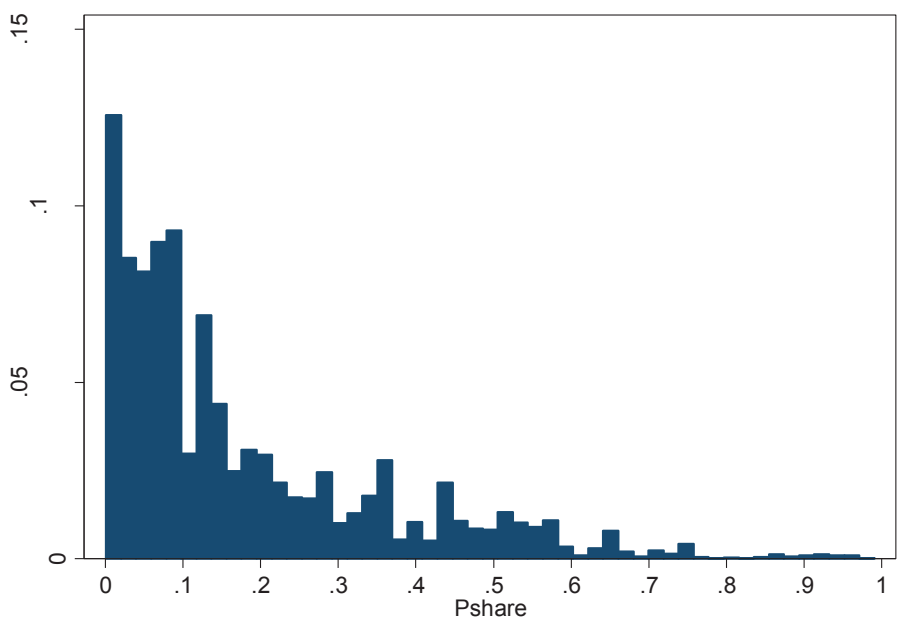

Firm

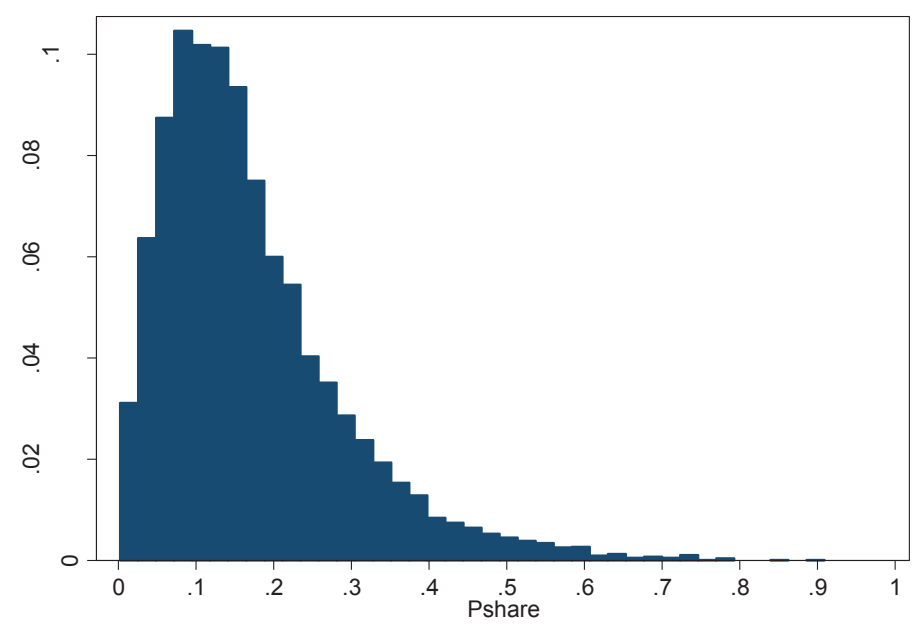

Notes: $N=1,184,004$ workers (left Panel), 9,072 firms (right Panel). The variable represents the share of public sector employment in 2002 in labor market cells defined by 2 genders, 3 experience categories, 7 occupational categories and 21 counties. In the left panel the variable is defined at the worker level, in the right panel at the firm level. 
Table A1: Share of Public Sector in Labor Market Segments Defined by Gender, Experience and Occupation

\begin{tabular}{lcc}
\hline Year & Pshare & Pshare Firm \\
\hline Constant & $0.168^{* *}$ & $0.167^{* *}$ \\
& $(0.001)$ & $(0.003)$ \\
1999 & $-0.008^{* *}$ & $-0.012^{* *}$ \\
& $(0.001)$ & $(0.005)$ \\
2000 & $-0.011^{* *}$ & -0.008 \\
& $(0.001)$ & $(0.005)$ \\
2001 & $-0.011^{* *}$ & -0.008 \\
& $(0.001)$ & $(0.004)$ \\
2002 & $-0.003^{* *}$ & -0.008 \\
& $(0.001)$ & $(0.004)$ \\
2003 & $0.007^{* *}$ & 0.002 \\
& $(0.001)$ & $(0.004)$ \\
2004 & $0.004^{* *}$ & 0.003 \\
& $(0.001)$ & $(0.005)$ \\
2005 & $-0.006^{* *}$ & -0.006 \\
& $(0.001)$ & $(0.005)$ \\
2006 & 0.001 & -0.001 \\
& $(0.001)$ & $(0.005)$ \\
\hline $\mathrm{R}^{2}$ & 0.001 & 0.001 \\
$\mathrm{~N}$ & $1,184,004$ & 87,387 \\
\hline Notes: Pshare $=$ the proportion of public sector workers in labor market \\
segments defined by gender, labor market experience, occupation and county. \\
Pshare Firm = the average of Pshare at the firm-year level. The regressions are \\
weighted with population weights. $* *$ significant at the $1-$ percent level; * \\
significant at the 5-percent level.
\end{tabular}


Table A2: Changes in the Gender Wage Gap and Skill Premium

\begin{tabular}{|c|c|c|}
\hline & $\begin{array}{c}\text { Gender } \\
\text { Wage Gap }\end{array}$ & Skill Premium \\
\hline Female After & $\begin{array}{c}0.015^{* *} \\
(0.003) \\
\end{array}$ & \\
\hline High-skilled After & & $\begin{array}{c}0.032^{* *} \\
(0.004)\end{array}$ \\
\hline $\mathrm{R}^{2}$ & 0.475 & 0.434 \\
\hline \multicolumn{3}{|c|}{$\begin{array}{l}\text { Notes: } N=1,184,004 \text {. Dependent variable: log wage. "After" }=1 \text { for the years } \\
2003 \text { to 2006. The regressions include controls for gender, experience, } \\
\text { occupation, county, average wage in the public sector, industry effects, year } \\
\text { effects and firm fixed-effects. Standard errors clustered at the firm level. The } \\
\text { regressions are weighted with population weights. }{ }^{* *}=\text { significant at the } 1 \text { - } \\
\text { percent level; }{ }^{*}=\text { significant at the } 5 \text {-percent level. }\end{array}$} \\
\hline
\end{tabular}


Table A3: Yearly Effect of Public Sector Exposure on Corporate Wages

\begin{tabular}{lll}
\hline & Psharelnd & PshareFirm \\
\hline 1998 & $-0.036^{* *}$ & -0.060 \\
& $(0.014)$ & $(0.034)$ \\
1999 & -0.019 & -0.040 \\
& $(0.012)$ & $(0.028)$ \\
2000 & $-0.054^{* *}$ & $-0.136^{* *}$ \\
& $(0.011)$ & $(0.030)$ \\
2001 & $-0.030^{* *}$ & $-0.123^{* *}$ \\
& $(0.009)$ & $(0.022)$ \\
2003 & $0.034^{* *}$ & $0.038^{*}$ \\
& $(0.008)$ & $(0.016)$ \\
2004 & $0.021^{*}$ & $0.100^{* *}$ \\
& $(0.010)$ & $(0.021)$ \\
2005 & 0.010 & $0.140^{* *}$ \\
& $(0.011)$ & $(0.023)$ \\
2006 & 0.007 & $0.118^{* *}$ \\
& $(0.014)$ & $(0.029)$ \\
\hline $\mathrm{R}^{2}$ & & \\
$\mathrm{~N}$ & & 0.934 \\
\hline
\end{tabular}

Notes: Dependent variable: log(wage). Each regression controls for log average public sector wage in the labor market sector, net migration at the county level, industry and year fixed effects, and worker-firm joint fixed effects. Standard errors clustered at the worker-firm level. The regressions are weighted with population weights. ${ }^{* *}=$ significant at the 1 -percent level; ${ }^{*}=$ significant at the 5-percent level. 
MNB WORKING PAPERS 2017/4

PUBLIC WAGE SPILLOVERS:

THE ROLE OF INDIVIDUAL CHARACTERISTICS AND EMPLOYER WAGE POLICIES

Print: Prospektus-SPL consortium

H-8200 Veszprém, Tartu u. 6. 


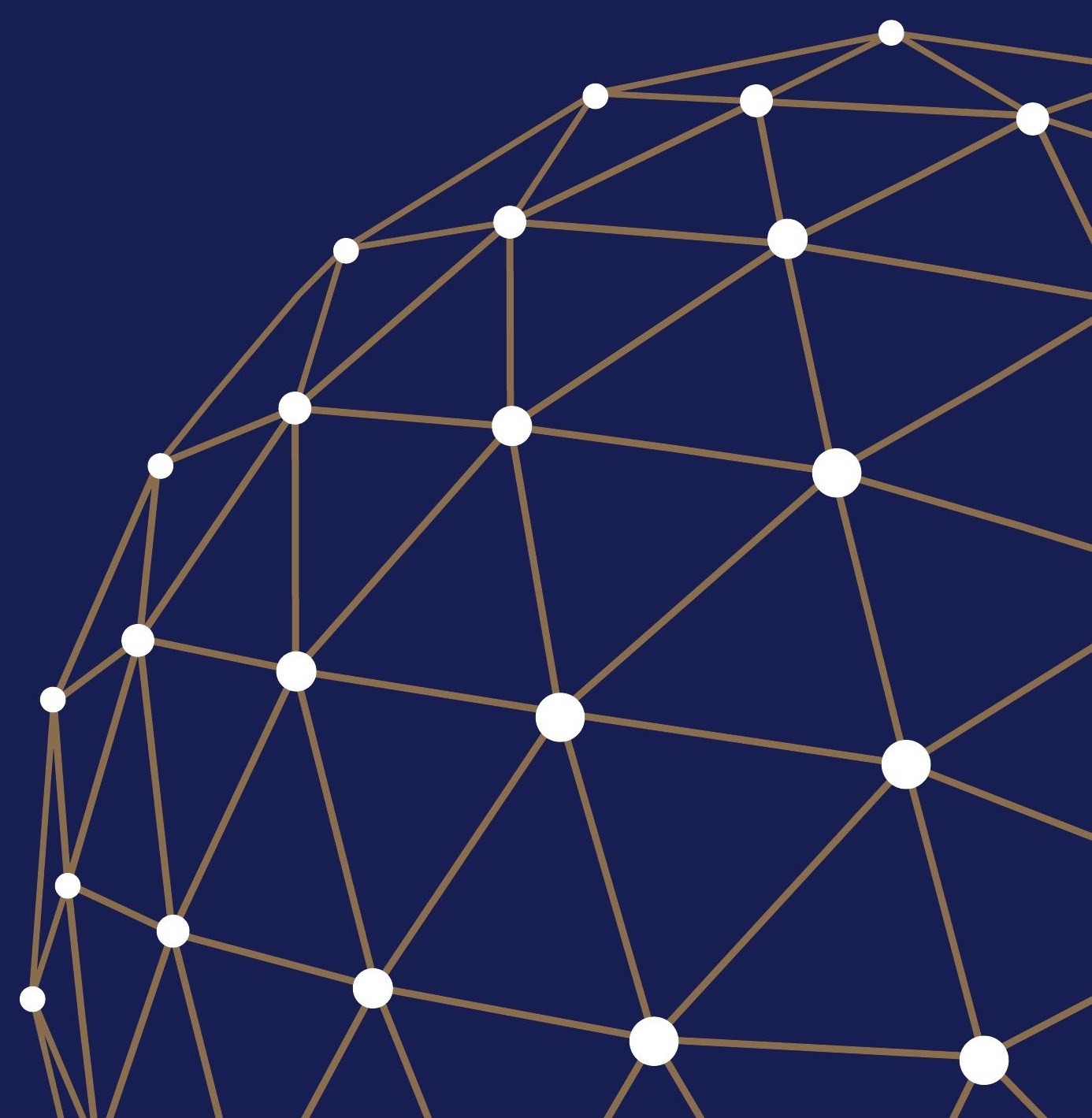

